\title{
Vector-Focused Approaches to Curb Malaria Transmission in the Brazilian Amazon: An Overview of Current and Future Challenges and Strategies
}

\author{
Elerson Matos Rocha ${ }^{1}$, Ricardo de Melo Katak ${ }^{1}$, Juan Campos de Oliveira ${ }^{1}$,

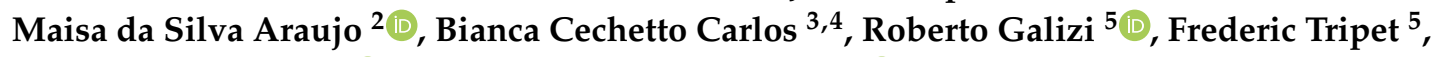 \\ Osvaldo Marinotti ${ }^{6, *(D)}$ and Jayme A. Souza-Neto ${ }^{3,4, *(1)}$ \\ 1 Programa de Pós-Graduação em Biotecnologia, Universidade Federal do Amazonas-PPGBIOTEC/UFAM, \\ Manaus 69067-005, Brazil; elerson.matos@hotmail.com (E.M.R.); ricardokatak@hotmail.com (R.d.M.K.); \\ juanbio1807@gmail.com (J.C.d.O.) \\ 2 Laboratory of Medical Entomology, Oswaldo Cruz Foundation, FIOCRUZ RONDONIA, Porto Velho, \\ RO 76812-245, Brazil; maisaraujo@gmail.com \\ 3 Department of Bioprocesses and Biotechnology, School of Agricultural Sciences, São Paulo State \\ University (UNESP), Botucatu 18610-034, Brazil; bc.carlos@unesp.br \\ 4 Central Multiuser Laboratory, School of Agricultural Sciences, São Paulo State University (UNESP), \\ Botucatu 18610-034, Brazil \\ 5 Centre of Applied Entomology and Parasitology, School of Life Sciences, Keele University, Staffordshire ST5 \\ 5GB, UK; r.galizi@keele.ac.uk (R.G.); f.tripet@keele.ac.uk (F.T.) \\ 6 MTEKPrime, Aliso Viejo, CA 92656, USA \\ * Correspondence: omarinotti@gmail.com (O.M.); jayme.souza-neto@unesp.br (J.A.S.-N.)
}

Received: 18 September 2020; Accepted: 13 October 2020; Published: 20 October 2020

check for updates

\begin{abstract}
In Brazil, malaria transmission is mostly confined to the Amazon, where substantial progress has been made towards disease control in the past decade. Vector control has been historically considered a fundamental part of the main malaria control programs implemented in Brazil. However, the conventional vector-control tools have been insufficient to control or eliminate local vector populations due to the complexity of the Amazonian rainforest environment and ecological features of malaria vector species in the Amazon, especially Anopheles darlingi. Malaria elimination in Brazil and worldwide eradication will require a combination of conventional and new approaches that takes into account the regional specificities of vector populations and malaria transmission dynamics. Here we present an overview on both conventional and novel promising vector-focused tools to curb malaria transmission in the Brazilian Amazon. If well designed and employed, vector-based approaches may improve the implementation of malaria-control programs, particularly in remote or difficult-to-access areas and in regions where existing interventions have been unable to eliminate disease transmission. However, much effort still has to be put into research expanding the knowledge of neotropical malaria vectors to set the steppingstones for the optimization of conventional and development of innovative vector-control tools.
\end{abstract}

Keywords: malaria; Amazon; Brazil; Anopheles darlingi; Plasmodium; control; challenges; strategies; conventional; novel; vector; mosquito

\section{Introduction}

Malaria eradication, defined as the permanent reduction to zero of the worldwide incidence of malaria infection, has been a major global and public health objective for decades. Progress toward eradication includes efforts for controlling and eventually eliminating malaria in specific geographic 
areas or countries. While control measures aim at reducing the number of new infections and the number of people infected in local settings, malaria elimination is accomplished when transmission ceases completely to occur locally. To achieve malaria elimination in Brazil and worldwide eradication, a combination of conventional and new approaches and tools will be necessary [1,2].

In 2015, the World Health Organization (WHO) adopted The Global Technical Strategy for Malaria 2016-2030, providing guidance to countries in their efforts to achieve malaria elimination and setting a goal of reducing global malaria incidence and mortality rates by at least $90 \%$ by 2030 [3,4]. The Pan American Health Organization (PAHO) followed with the resolution CD55.R7, a plan of action for malaria elimination in the Americas [5]. In the same year, the Brazilian National Malaria Control Program (NMCP) of the Ministry of Health launched a plan for elimination of the malaria-causing parasite Plasmodium falciparum in Brazil [6], acknowledging that Plasmodium vivax elimination is more challenging and may take longer, requiring specific tools and strategies for its containment, especially regarding the prevention of relapses [7].

Malaria is a vector-borne disease transmitted by anopheline mosquitoes [8]. Hence, vector control is a vital component of malaria prevention, control and elimination strategies [8,9]. Here we review malaria control measures focused on mosquito vectors presently applied in the Brazilian Amazon and discuss their advantages and limitations. Furthermore, we discuss progresses in innovative vector control approaches aimed at curbing malaria transmission, which once fully developed may be incorporated into integrated mosquito management programs.

\section{Malaria in Brazil, a Brief History and Current Status}

In Brazil, malaria affecting members of the native Tupinambá people was first reported in 1587, however, no epidemics were reported during the colonial period [10,11]. By the end of the 19th century and beginning of the 20th century, in a changed scenario, malaria was endemic throughout the country, with approximately 6 million cases per year [10]. Since then, the disease has virtually been eliminated in the southern areas, where nowadays only a few cases of autochthonous malaria transmission are reported annually [12,13]. In contrast, malaria remains a major public health problem in Northern Brazil, mostly in the Amazon region where more than 99\% of the country's malaria cases currently occur $[14,15]$.

The first noticeable increase in the number of malaria cases in the Amazon region occurred during the Amazon Rubber Boom (1879 to 1912), when approximately half a million immigrants moved to the area attracted by job opportunities in latex extraction, natural rubber industrial processing and related activities. Railroads were built to facilitate the transport and export of rubber products and improve accessibility to settled but isolated areas. One of these, the Madeira Mamoré railway, built between 1907 and 1912, was nicknamed the "Devil Railway" because thousands of workers died during its construction [10], largely due to the high number of mosquitoes spreading malaria in the settlements [16]. Just a few decades later, in the 1930s, Anopheles arabiensis, coming from Africa by sea, was introduced in Brazil [17,18]. The spread of this efficient vector throughout Northeastern Brazil resulted in an epidemic with more than 150,000 cases and 14,000 deaths from malaria between 1938 and 1939. Fortunately, the invasive An. arabiensis population was eliminated in 1940, thanks to management of breeding sites and insecticides sprayed in homes and vehicles [19-21].

Despite the elimination of An. arabiensis in the early 1940s, malaria continued to be transmitted in the Amazonian states by local anopheline vectors, with estimates of six to eight million people infected and 80,000 deaths annually during that decade [13]. In 1947, the Brazilian National Malaria Service implemented the use of dichlorodiphenyltrichloroethane (DDT) for vector control, and in 1950 of chloroquine for the treatment of patients infected with parasites [22,23]. These measures resulted in significant reduction of malaria transmission, with only 36,900 cases reported in 1961 [19,22]. The spread of malaria in the Brazilian Amazon increased again in the 60's with the building of new roads, followed in the 70's with the establishment of hydroelectric projects and in the 80's with the emergence of the gold prospecting sites [24,25]. 
In the early 1970s, another immigratory flow was triggered by land ownership opportunities in the Amazon region, when the National Institute for Colonization and Agrarian Reform - INCRA was donating plots nearby the new road network [26,27]. These immigrants, unprepared and unaware, entered a region infested by mosquitoes, resulting in an epidemic with numbers that reached 300,000 cases in a population of 1 million inhabitants in Rondônia state alone [19,25,26,28]. In addition to the migratory wave, between 1970 and 1980, the increase in malaria cases in the Amazonian region was fueled by cuts in funding to sustain the social sectors, including vector control programs [29].

From 1990 to 2006, an average of 600,000 malaria cases were recorded annually [19,20], however, intensification of vector control and other malaria prevention and treatment measures in the following years resulted in a steady and significant reduction in the incidence of malaria [28,30]. Transmission intensity was maintained at 140,000 cases yearly in 2014, 2015 and 2016. However, in 2017 and 2018, 197,000 and 207,000 cases were registered respectively, a considerable growth compared to previous years [8]. The recent increase in reported malaria cases is mostly due to transmission occurring near the borders between Brazil and its neighbors French Guiana and Venezuela [31-33]. A timeline of malaria in the Brazilian Amazon is presented in Figure 1.

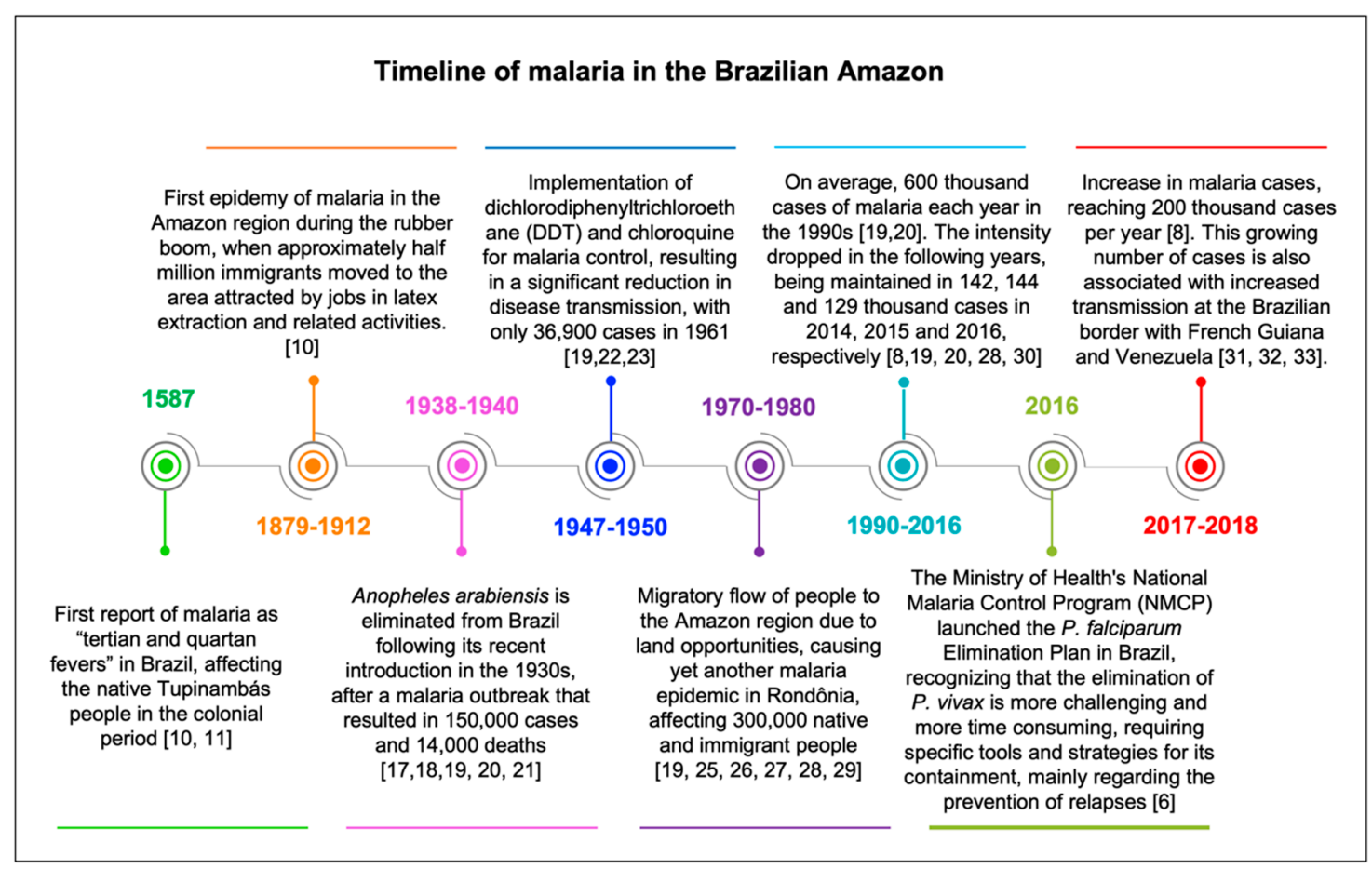

Figure 1. Timeline of the main events concerning malaria transmission and control in the Brazilian Amazon.

\section{Malaria Vectors in the Brazilian Amazon and the Importance of Vector Population Surveillance}

Effective vector control in the Amazon is a complex and multifactorial task because of the sheer geographical scale of the region, its markedly heterogeneous ecology and complex human demographic aspects [34]. Urban, peri-urban and rural environments, as well as other areas of special interest, as described below, present their unique challenges for controlling malaria transmission. Mosquito density and ecology as well as environmental conditions and human activity must be considered when designing vector-control measures adapted to regional specificities (Figure 2). 


\section{Challenges for malaria vector control}
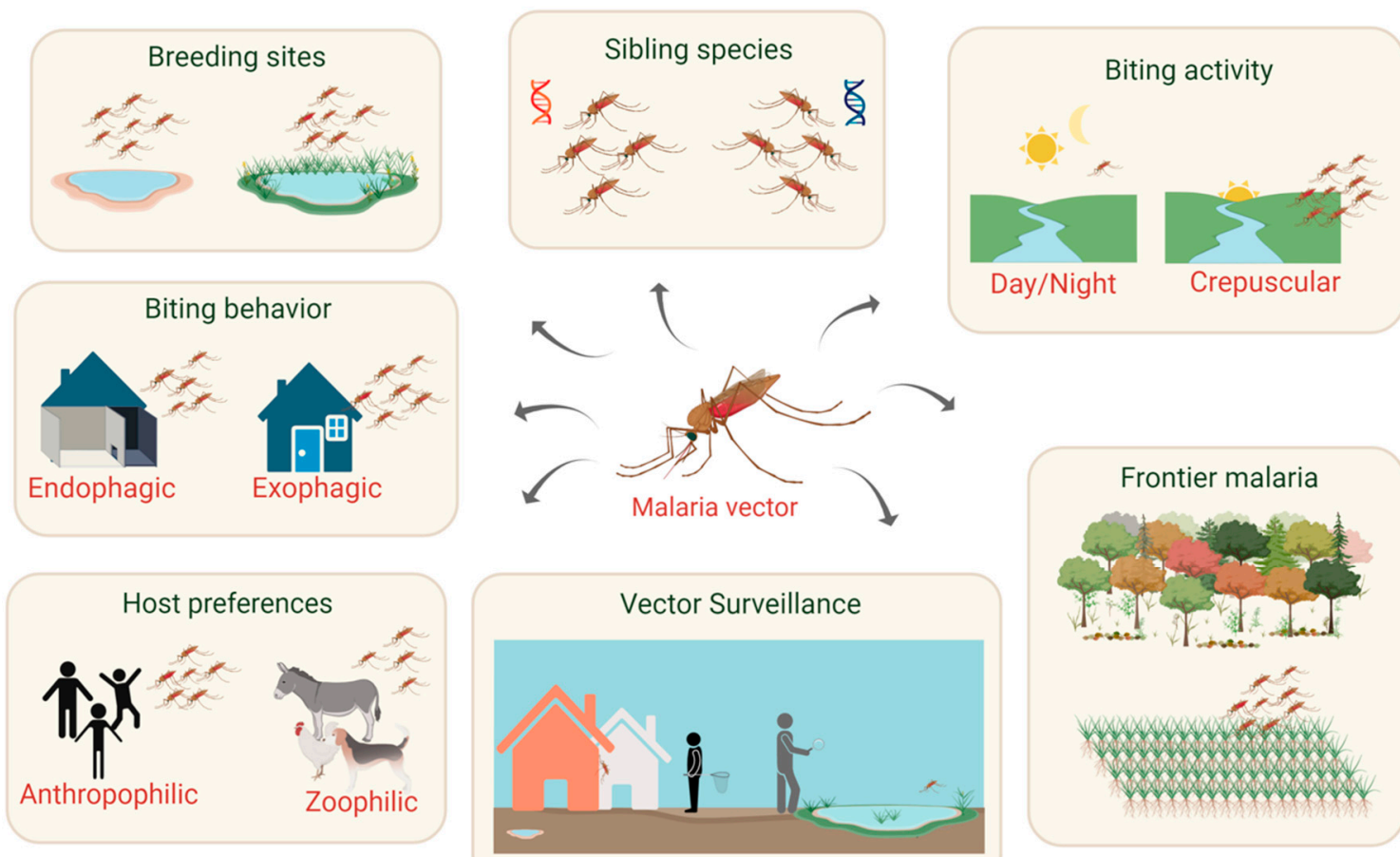

Figure 2. Main challenges for the development of novel vector-focused malaria control tools. Created with BioRender.com.

For instance, malaria control in areas of special interest such as native people settlements, areas of mining and national borders, present their own challenges. Malaria incidence in Brazilian native people is associated with environmental changes, their difficulty in accessing health services, and their mobility, at times resulting in migration to areas of more intense malaria transmission [35,36]. Furthermore, culturally determined activities such as hunting, fishing, working in the fields, and bathing along rivers and streams expose indigenous people to the risk of malaria infection. Gold mining plays a major role in spreading malaria in the area [37] since this activity creates puddles of water, ideal habitat for the reproduction of Anopheles mosquitoes. Transmission of malaria among miners (garimpeiros) is greatly affected by their constant mobility and a work regime that coincides with the peak of biting activity of vector mosquitoes. Populations of border towns are generally more vulnerable, especially those living in remote areas, as recently observed along the border between French Guiana and Brazil where local inhabitants were affected by a malaria outbreak [38]. Recent events in Venezuela, causing mass migrations, have been responsible for an increase in malaria transmission across the frontier between Brazil and Venezuela [31,32]. Each one of these scenarios demand unique malaria control programs that include vector-control measures adapted to the regional context.

A total of fifty-four species of Anopheles are known to occur in Brazil, 33 of which are found in the Amazon region $[39,40]$. Anopheles darlingi, An. albitarsis, An. braziliensis, An. nunesztovari, An. oswaldoi, An. triannulatus, An. mattogrossensis, An. mediopunctatus and An. peryassui among other anopheline species are found throughout the Amazonian region [28] (Figure 3). All of those listed above are susceptible to natural Plasmodium infection, as demonstrated by using ELISA detection of the circumsporozoite protein (CSP), microscopy and/or PCR [28,41]. Among those, the primary vector in the Amazonian Rainforest malaria transmission system is An. darlingi [28], which is abundant and highly anthropophilic $[42,43]$. Anopheles darlingi readily adapts to environmental changes caused by human activity and can easily develop in either artificial breeding sites such as fish farm tanks or in the midst of nature [44,45]. While one must recognize the economic importance of fish farming in the 
Brazilian Amazon region, its contribution to increased vector populations and malaria transmission is clear. Active and abandoned fishponds with shaded, deep, clean waters and surrounded by vegetation without consistent cleaning of their borders, may form suitable breeding sites for An. darlingi and other anopheline mosquitoes [46].

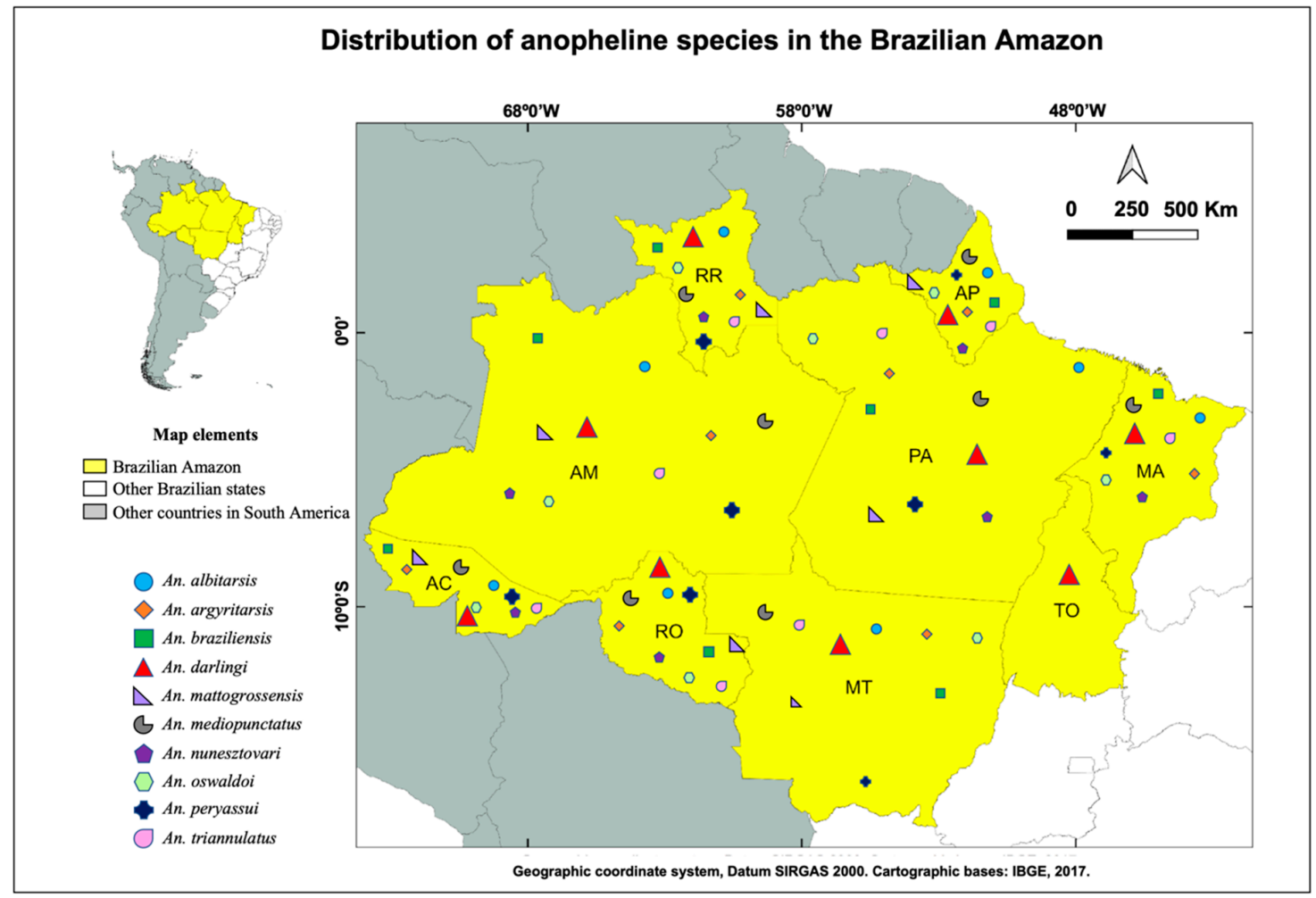

Figure 3. Distribution of the main anopheline species known to occur in the Brazilian Amazon, with emphasis in Anopheles darlingi, the main malaria vector in the region. The mosquito species distribution was carried out according to a database previously published by [28].

Vector surveillance is essential to inform vector control strategies and evaluate their impact on malaria transmission. In the Amazon, vector surveillance has evidenced geographical and temporal differences in mosquito densities and species composition in malaria endemic areas [39,47]. Factors driving this diversity are environmental [48,49], anthropogenic [45] and biological [39,50]. Hydrological cycles of the Amazon region include heavy rainfall between the months of November and June, resulting in the flooding of approximately $85,000 \mathrm{~km}^{2}$ of the Amazonian plain [51]. The end of each flooding cycle creates numerous large and small pools of water and slow-flowing streams suitable for mosquito breeding, as water levels slowly recede along rivers [45]. The large-scale climate interaction caused by environmental phenomena like the El Niño are associated with warmer temperatures, higher dew points, as well as reduced precipitation and river discharge in the Amazon, which may influence the dynamics of malaria transmission $[52,53]$.

Anthropic activity in the Amazon has been associated with "Frontier malaria" a term commonly used to describe malaria transmission related with deforestation and with the unplanned development of new agricultural settlements [54]. Newly deforested areas create multiple new An. darlingi breeding sites, favoring malaria transmission [55,56]. However, anthropic activity may favor other vector species too. In Macapa, such changes reduced the suitability of breeding sites for An. darlingi and led to an increased density of An. marajoara [57].

Phenotypic plasticity, including features such as anthropophily and endo-exophily, have been revealed by entomological surveys of neotropical malaria vectors [58,59]. Anopheles darlingi typically displays a single peak of biting activity before midnight [60-65], however, in certain areas two peaks of 
biting activity are observed: one at dusk and another at dawn [66-70]. Furthermore, An. darlingi biting activity may occur in three peaks at sunset, midnight and dawn [71]. Observations at one locality showed considerable plasticity of this species' biting patterns as well, indicating that intra-population variation of biting activity can be as significant as inter-population variation [72]. Single or multiple blood meals in each gonotrophic cycle, determined by biological or environmental factors, also may influence the vectorial capacity of malaria mosquitoes [73].

The investigation of cryptic species among neotropical malaria vectors is essential for a better understanding of species distributions, behavior and population dynamics, leading to a better understanding of malaria transmission and adequate strategies for effective vector control in the Amazon. In Africa and in Asia, several of the major malaria vectors belong to species complexes, including cryptic species that differ in host feeding preference, breeding sites, feeding behavior, and role in malaria transmission [74-76]. These complexes may include both malaria vectors and non-vector species, which may either occur sympatrically or have distinct geographical distributions. While An. darlingi, the major malaria vector in the Brazilian Amazon, is a monotypic species, other neotropical malaria vectors such as An. nuneztovari, An. albitarsis, An. triannulatus and An. oswaldoi are complexes of closely related, morphologically similar species [77]. For instance, An. konderi is often mistaken for $A n$. oswaldoi [78], however An. konderi is present in human impacted or open areas, whereas An. oswaldoi is restricted to forested ones [79]. Marrelli et al. (1999) observed that both An. oswaldoi and An. konderi developed P. vivax oocysts in their midgut, but the complete cycle of the parasite, with sporozoites reaching the salivary glands, was only observed in An. oswaldoi, suggesting these species differ in vector competence [80]. Therefore, the refinement of taxonomic tools, including molecular taxonomic tools $[81,82]$ is paramount for the knowledge and understanding of the biology of these neotropical species complexes and for the investigation of malaria epidemiology. Furthermore, proper identification of species and knowledge of their ranges, often affected by changes in land use and lately in the climate, is vital for appropriate allocation of vector control resources.

\section{Conventional Measures for Vector Control and Their Limitations}

The core and supplemental interventions for malaria vector control advocated by the World Health Organization and the Brazilian Ministry of Health are very similar as they represent a set of evidence-based guidelines (Table 1). The Brazilian Health Ministry acknowledges that not all areas should be subject to the same malaria control programs and follows a decentralized system in which each municipality adopts different control strategies. Also, it recognizes the existence of areas of special importance that are particularly vulnerable and with limited access to interventions. These include: Indigenous areas/indigenous tribes; gold mining camps; settlement areas; and frontier areas in the northern and western Brazilian Amazon rainforest.

Table 1. Current Guidelines for Malaria Vector Control in the World and in Brazil.

\begin{tabular}{cc}
\hline World Health Organization & Brazilian Ministry of Health \\
\hline GUIDELINES FOR MALARIA VECTOR CONTROL & Malária: o que é, causas, sintomas, tratamento, \\
2019 [83] & diagnóstico e prevenção, accessed on May 5, 2020 [14] \\
Malaria vector control, Policy guidance, & Plano de Eliminação da Malária no Brasil 2016 [6] \\
Recommendations, accessed on May 5, 2020 [84] & Guia de tratamento da malária no Brasil 2020 [86] \\
$\begin{array}{c}\text { Malaria vector control, Policy guidance, Operational } \\
\text { manuals, accessed on May 5, 2020 [85] }\end{array}$ & \\
\hline
\end{tabular}


Table 1. Cont.

\section{Core interventions}

INSECTICIDE-TREATED NETS: Pyrethroid-only

Long-lasting insecticidal nets (LLINs) prequalified by

WHO are recommended for deployment as a core intervention in all malaria-endemic settings.

Pyrethroid-PBO nets prequalified by WHO are conditionally recommended for deployment instead of pyrethroid-only LLINs where the principal malaria vector(s) exhibit pyrethroid resistance.

Strongly recommended as an intervention of public health value, high-certainty evidence.

\section{INDOOR RESIDUAL SPRAYING (IRS):}

IRS deploying a product prequalified by $\mathrm{WHO}$ is recommended as a core intervention in all malaria-endemic settings. DDT has not been prequalified; it may be used for IRS if no equally effective and efficient alternative is available, and if it is used in line with the Stockholm Convention on Persistent Organic Pollutants.

Strongly recommended as an intervention of public health value, low-certainty evidence.
INSECTICIDE-TREATED NETS: Use of long-lasting impregnated mosquito nets in priority locations for each municipality and increase coverage in locations where LLIN is already used, together with monitoring of LLIN replacement plan to ensure availability.

INDOOR RESIDUAL SPRAYING: IRS following technical recommendations of

the Brazilian Health Surveillance Secretariat (SVS), in

buildings located in areas responsible for $80 \%$ of malaria transmission by

Infection, and in cycles that allow residual insecticide to be maintained throughout the year.

HOUSING AND WORKING PLACE

IMPROVEMENT: doors and windows screen installation and maintenance.

\begin{tabular}{|c|c|}
\hline \multicolumn{2}{|c|}{ Supplementary interventions } \\
\hline $\begin{array}{l}\text { LARVICIDING: Regular application of biological or } \\
\text { chemical insecticides to water bodies is } \\
\text { recommended in areas where high coverage with a } \\
\text { core intervention has been achieved, where aquatic } \\
\text { habitats of the principal malaria vector(s) are few, } \\
\text { fixed and findable, and where its application is both } \\
\text { feasible and cost-effective. Conditionally } \\
\text { recommended as an intervention of public health } \\
\text { value, low-certainty evidence. }\end{array}$ & $\begin{array}{l}\text { LARVICIDING: Carrying out management of water } \\
\text { collections to eliminate breeding sites } \\
\text { of anopheline mosquitoes in urban locations with } \\
\text { malaria transmission. Drainage; minor sanitation } \\
\text { work to eliminate vector breeding sites; landfill; } \\
\text { cleaning the margins of breeding sites; modification } \\
\text { of water flow; control of aquatic vegetation. }\end{array}$ \\
\hline
\end{tabular}

TOPICAL REPELLENTS: Deployment of topical repellents is not recommended as a public health intervention; however, topical repellents may be beneficial as an intervention to provide personal protection.

Conditionally recommended against deployment as TOPICAL REPELLENTS:

DEET (N-N-dietilmetatoluamida) an intervention with public health value, low-certainty evidence.

INSECTICIDE-TREATED CLOTHING: Use of

insecticide-treated clothing is not recommended as an intervention with public health value; however, insecticide-treated clothing may be beneficial as an intervention to provide personal protection in specific population groups.

Conditionally recommended against deployment as an intervention with public health value, low-certainty evidence.

SPACE SPRAYING: Space spraying should not be undertaken for malaria control, and IRS or LLINs should be prioritized instead.

Conditionally recommended against deployment,

SPACE SPRAYING: Performing chemical spatial control, when in outbreak situations. 


\subsection{Long-Lasting Insecticidal Nets (LLINs)}

The use of LLINs is a highly cost-effective strategy for malaria prevention that has contributed to a significant reduction in disease morbidity and mortality worldwide. Until 2007, the WHO advocated distribution of LLINs only to pregnant women, children, and human immunodeficiency virus (HIV)-positive individuals. Since then, LLINs are recommended by WHO to all individuals at risk in endemic areas [87]. Accordingly, in Brazil, the Ministry of Health recommends the distribution and installation of LLINs, which are intended for personal overnight protection. Currently, LLINs impregnated with pyrethroid have a shelf life of less than 3 years [88-90]. Insecticide-treated bed-net incorporating a mixture of the pyrethroid alpha-cypermethrin and pyriproxyfen, an insect growth regulator, has been proposed as an alternative to pyrethroid-only nets. Experimental evaluations showed more than $80 \%$ mortality and higher than $90 \%$ blood-feeding inhibition in the African malaria vector An. gambiae exposed to these LLINs. Furthermore, blood-fed female mosquitoes surviving net exposure suffered $83 \%$ reduction in oviposition and $95 \%$ reduction in offspring, indicating a potential improvement of malaria vector control when compared to standard pyrethroid-only LLINs [91]. Insecticide-treated nets with other insecticide combinations such as chlorfenapyr and alpha-cypermethrin, have also been proposed as tools for controlling malaria vector mosquitoes [92]. Impregnation of mosquito nets with antimalarial drugs has been suggested as an alternative to mitigate the problem of insecticide resistance [93]. Evidence-based discussion is needed before these novel mosquito nets enter the development pipeline.

Three-hundred-thousand LLINs have been purchased by the Ministry of Health between 2015 and today. Despite the advantages of using LLINs subsidized by the government, data regarding the actual distribution and use of impregnated mosquito nets in this region is scarce [94,95]. Local surveys indicate negative perceptions of LLINs, as they may cause skin irritations and allergies and are not effective in preventing malaria transmission occurring outdoors [96]. Low compliance, net misuse, lack of LLIN replacement program, and local epidemiological factors may curtail the efficacy of impregnated bed nets for malaria control in the Amazon region.

\subsection{Indoor Residual Spraying (IRS)}

Another core measure for malaria vector control consists of spraying the walls of commercial buildings and residences with insecticides that remain on the applied surfaces [97]. Etofenprox PM $20 \%$ is the insecticide used in Brazil for residual spraying for malaria vector control. This product has a residual effect for 4 months requiring three annual applications [88]. In the Amazon, factors such as the operational cost of mobilizing teams to perform insecticide spraying, the difficulty in accessing remote areas at adequate frequency, the variability of dwellings, and variable environmental conditions, may compromise the efficacy of IRS [98]. In fact, few systematic evaluations on the impact these measures have on suppressing anopheline populations and reducing levels of malaria transmission in the Brazilian Amazon have been performed [88,98]. While IRS is applicable and effective in urban and peri-urban environments, issues need to be addressed regarding gold miners who often live in huts without walls, continuously exposed to mosquito bites; unconventional indigenous house architecture that may not favor IRS; and the lack of studies regarding the stability of insecticides applied on unconventional surfaces and under extreme humidity and temperature environmental conditions [99]. Investments in next generation log lasting insecticides and advances in IRS management and application equipment have offered promising results for effective future application of IRS in the Brazilian Amazon [100,101].

\subsection{Larvae Control}

Supplemental interventions based on larval control are effective in reducing vector density and malaria transmission where aquatic habitats of the principal malaria vector(s) are few, fixed and findable, and where its application is both feasible and cost-effective [102-104]. Historical interventions, 
largely based on larval control, including the previously mentioned eradication of An. arabiensis from Brazil [105], suggest that this approach may be an important asset in the battle for achieving malaria elimination and eradication.

Early larvicidal interventions involved environmentally damaging measures including the elimination of breeding sites by filling depressions or draining swamps, and the application of toxic diesel or Paris green, impacting all organisms living in ponds, swamps, and other breeding sites. Nowadays, environmentally friendly alternatives are widely available. For example, biolarvicides based on the bacteria Bacillus thuringiensis israelensis (Bti) and/or Lysinibacillus sphaericus, (syn. Bacillus sphaericus, Bs) have been successfully applied for mosquito control in various ecological settings in sub Saharan Africa [106], Europe [107], Asia [108] and South America [109]. Aquatic insect predators and larvivorous fish have also been proposed as mosquito biocontrol agents, however, there is only limited evidence of their impact on disease transmission [110]. Density, diversity and habitat effects on the efficacy of natural mosquito larvae enemies must be considered. For instance, the presence of alternative preys, normally present in the extremely biodiverse Amazonian environment, together with the scarce selectivity of predators may limit the impact of such approaches on mosquito population [111].

Larvae control interventions require substantial knowledge of larval ecology due to the effects of weather and physical and biological characteristics of larval habitats on their efficacy. Furthermore, larviciding interventions are labor-intensive and to be effective must cover multiple Anopheles larval habitats often dispersed in vast areas [106]. Therefore, the effectiveness of larvicides in the Amazon is limited to urban and peri urban environments, during the dry season and where the number of mosquito breeding sites is limited and easily accessible. Larviciding is not recommendable when and where breeding sites are inaccessible and countless, and in rural and frontier environments. Because of the territorial dimensions of the Amazon and the characteristics of breeding sites, in rural areas this procedure is restricted to the vicinity of inhabited settlements in ranches and farms and fishponds [112]. Recent developments using unmanned aerial vehicles coupled with high-resolution multispectral imagery to locate anopheline breeding sites could contribute to lower costs and improve the coverage of larvae control programs in the Amazonian region [113,114].

\subsection{Personal Protection}

Supplementary prophylactic measures against malaria include personal protection such as screens installed in windows and doors, clothing covering exposed parts of the body during biting periods, mosquito repellents, insecticides and air-conditioning [115]. Although highly recommended for travelers entering malaria endemic areas [116], most types of continuous personal protection may be neither reasonable nor affordable for local inhabitants due to economic and cultural issues. The typical climate conditions of the Amazon, with both high temperature and humidity, make wearing long sleeves shirts and pants uncomfortable as a way of mosquito bite protection. Insecticide impregnated clothing is expensive and requires replacement or special treatment to maintain its protective function [117]. Mosquito repellents require continuous reapplication and costs may be prohibitive. In Brazil DEET-based products $(100 \mathrm{~mL}$, of $6.7-7.1 \%$ DEET) costs on average $15.80 \mathrm{BRL}$ equivalent to US\$3.84 [118]. Furthermore, the efficacy of commercially available repellents in protecting people from neotropical anophelines bites is still largely unknown. Local insecticide spraying is only manageable, sustainable and effective in confined environments, and its continuous application harms the environment [119]. Finally, housing improvements including netting and air conditioning are dependent on traditional architecture, windows and doors, as well as access to electricity and sufficient income that allows purchase, installation and maintenance of such home improvements.

A large body of work is now emerging on housing improvement and materials for malaria control. Lethal house lures, insecticide or mosquito repellent-treated furniture and sandals, and materials for temporary shelters, are offering new tools that can be applied to both stable and traditional or temporary housing settings [120-125]. These advances, once implemented in the Amazon, could constitute a scalable and low-cost supplement to current malaria control interventions. 


\section{Promising Novel Vector Control Approaches}

In view of the present limitations of conventional techniques for vector-focused malaria control in the Amazon, novel and promising approaches to curb malaria transmission are under investigation and consideration.

\subsection{Genetic Control of Malaria Vectors}

Genetic engineering of mosquitoes offers solutions and novel strategies to tackle the challenges encountered by current vector control interventions such as: difficulties in deploying control measures to the affected regions, largely rural and dispersed in large areas; the broad-spectrum activity of available insecticides and the spread of insecticide resistance. Such strategies rely on the release of modified insects carrying specific genetic traits, which act upon mating with the compatible species. This limits their impact on the ecosystem and, at the same time, facilitates the deployment of the intervention by taking advantage of the dispersal and mate-seeking behavior of the released mosquitoes.

\subsubsection{Population Suppression or Replacement}

Genetic control strategies can be aimed either at the "suppression" of the overall number of vectors or to their "replacement" with modified insects that are incapable or refractory to the transmission of the pathogen. Suppression strategies usually exploit the engineering of genetic traits that interfere with the reproductive capacity of insects and/or their fitness. Conversely, genetic modifications for population replacement involve the introduction and expression of exogenous antiparasitic genes or the editing of the genetic components involved in vector-pathogen interactions to block or reduce the parasite development within the vector. Replacement modifications can also be intended to hinder the host-seeking behavior of insects, thereby reducing their vector competence [126-128].

\subsubsection{Self-Limiting or Sustaining Strategies}

The genetic control traits carried by the modified insect can be engineered to achieve different levels of persistence in the population after being released; this may vary from one, up to a virtually unlimited number of generations. Classic sterile insect technique (SIT) relies on repeated inundative releases of radio or chemical-sterilized males, which can suppress the targeted populations by exploiting the single-mating capacity of female mosquitoes [129]. However, poor survival and mating competitiveness of the sterile males released are detrimental for the efficacy of these strategies [130].

The availability of genomic sequences and tools for the genetic modification of the mosquito genome allowed the engineering of alternative approaches based on the release of genetically modified male insects carrying a dominant lethal gene (RIDL), with the added benefit of a reduced impact on the fitness of released males compared to the classic methods [131]. With both approaches (SIT and RIDL), the sterile or dominant lethal traits carried by released males are not transmitted to the following generations minimizing long-term impacts and simplifying the risk assessment process leading to field applications. Both these technologies have been successfully applied for suppression of agricultural pests and vectors [131-134] including the New World screwworm fly Cochliomyia hominivorax (cause of myiasis) in several American and African countries [135,136], the malaria vector Anopheles albimanus in El Salvador [137], the dengue virus-transmitting Aedes aegypti in Brazil [138] and tsetse flies (Glossina spp.) carriers of the African trypanosomiasis (sleeping sickness) in the Zanzibar Island Unguja [139] among other examples. However, self-limiting methods, such as SIT and RIDL, require repeated mass releases of the modified insects, challenging their use for the treatment of large or remote geographic regions and/or non-isolated vector populations.

Beside the dominant sterility phenotype associated with these specific methods, genetic modifications are at best neutral or, in most of the cases, conferring a reduction of fitness to the carriers, resulting in a gradual removal of these traits from the population after release [140]. Approaches to overcome these limitations were theorized in the first half of the 20th century 
when both threshold-dependent and self-sustaining strategies were initially proposed $[129,141]$. Threshold-dependent strategies, such as genetic underdominance, involve the introduction of genetic elements able to invade a population only if seeded above a certain frequency, which depend upon the fitness of released insects relative to wildtype [142]. On the other hand, self-spreading technologies such as gene drives (GD) offer the advantage of reducing the size and the frequency of releases necessary to either suppress the targeted population or replace it with insects unable to transmit the parasite $[140,143,144]$.

GD elements can be engineered to bias their own transmission by hijacking the mendelian partition of genetic material during germline formation of the vectors hosting such modifications in their genome. For example, site-specific endonucleases, such as the increasingly popular CRISPR-Cas system, can be inserted into specific genomic sequences to disrupt the function of haplosufficient genes with a role on female development $[145,146]$ or fertility [147]. The same endonuclease, active during the diploid stages of germline formation, is programmed to cut the target site on the homologous chromosome (not containing the CRISPR drive element). The double-strand DNA break stimulates the homology directed repair (HDR) machinery of the germ cell to repair the broken chromosome by using its homologous twin, carrying the GD, as a genetic template. As a result, the GD element is copied ("homed") to the homologous chromosome and transmitted to the entire progeny, instead of only half, thereby increasing in frequency over generations $[140,144]$.

The short life cycle of mosquitoes allows a rapid increment of individuals heterozygous for the GD element (and the associated genetic disruption) in the population, even if released at low frequencies, progressively reducing the number of wildtypes. Mating between GD heterozygous mosquitoes generates individuals without functional copies of the targeted haplosufficient gene, manifesting the disruptive phenotype; e.g., female sterile [147] or intersex XX individuals [145], causing suppression of the population. In a recent work, the same CRISPR-based gene drive element was also linked to a second endonuclease, targeting the $X$ chromosome during male meiosis [148] and to bias transmission of sperm in favor of those carrying the unaffected $Y$ chromosome. As a result, super-mendelian transmission of the GD is accompanied by male-biased progenies, thus presenting the advantage of reducing the fraction of biting females whilst suppressing the population [146]. Similarly, CRISPR-based GD constructs homing in neutral genetic loci were also engineered to spread anti-parasite molecules through caged mosquito populations [149,150].

\subsubsection{Challenges, Alternatives and Transfer to Neotropical Species (e.g., An. darlingi)}

Besides the technical challenges, such as the selection of genetic resistance to the driving component or to the anti-malarial molecule, consistent research efforts have been focused over the last few years towards the development of new methods to limit or mitigate the spread of gene drive elements. The flexibility and modularity of CRISPR endonucleases prompted a variety of genetic control forms with reduced penetrance as well as the development of novel countermeasures to gene drive spread [151-155]. The rapid progress in the laboratory and the potentials offered by these technologies are progressively shifting challenges towards the assessment of risk and ecological impact, regulation and acceptance prior to field applications [156].

The flexibility offered by the molecular components used for genetic control offers the opportunity to transfer, with relative ease, these technologies to other species, such as An. darlingi, albeit the following resources are available: a laboratory-adapted inbred colony for genetic manipulation and testing in the laboratory; annotated genome and, favorable but not essential, a transcriptome for the selection of candidate genes and regulatory sequences for the expression of molecular effectors in the mosquitoes. Ad hoc transcriptomes may be unnecessary in the case orthologous genes may be retrievable from sibling species [157-161]. Successes with An. darlingi colonization [162-164] and genome sequence and annotation [165] and similar advances with other neotropical anophelines [166-169] offer optimism that these technologies will soon be transferred to neotropical Amazonian malaria vectors. 
The use of genetically engineered mosquitoes has the potential of being effective in controlling vector mosquito and/or disease transmission. However, the coexistence of multiple anopheline malaria vectors in the Amazon may pose a challenge for these novel control approaches. Furthermore, transgenic mosquitoes-based methods still require a great deal of work as research is at the trial stages. Efforts for improving sex separation, better transportation and release protocols are required for field optimization. Potential problems related to late accumulation of deleterious mutations on the transformed mosquito populations used for replacement or adaptation of the targeted parasites to the new populations still need to be addressed.

\subsection{Microbial-Based Approaches to Control Malaria Transmission and Malaria Vector Populations}

\subsubsection{Entomopathogenic Organisms}

Mosquitocidal microorganisms, including viruses, fungi and bacteria have been investigated as potential ecologically friendly alternatives to chemical insecticides [170-173]. Bacillus thuringiensis var. israelensis (Bti) and Lysinibacillus sphaericus or Bacillus sphaericus (Bs) selectively kill mosquito larvae and have been used for decades with high efficacy and safety records [174,175]. However, conventional Bti and Bs have low residual activity requiring repeated applications and increasing the cost of interventions $[176,177]$. Long-lasting microbial larvicide formulations with sustained release of Bti and Bs active ingredients for up to 6 months are currently commercially available [103,178-180]. These new long-lasting larvicidal formulations associated with the use of drones to identify and map mosquito breeding sites, and deliver aerial application of granular or aqueous Bti formulations, may assist in reducing the complex operational challenges that affect mosquito control in the Amazon environments $[113,181]$. Besides Bti and Bs, microorganisms such as the bacteria Chromobacterium sp. Panama [182,183] and the fungi Beauveria bassiana [184] and Metarhizium anisopliae [185], among others, have demonstrated mosquitocidal activities. The present challenge is to convert these promising observations into products that are ready to be incorporated in mosquito control interventions.

Genetic engineering methods have been proposed to increase the pathogenicity, improve longer-term efficacy, and prevent or delay insect resistance to entomopathogenic microorganisms [185,186]. The addition of Bti genes into Bs genomes to increase infectivity to mosquitoes $[187,188]$ and the expression of $B t i$ and non-Bti derived mosquito toxins in readily transformable microorganisms such as Chlorella desiccate, Pichia pastoris and Saccharomyces cerevisiae have been investigated as alternatives to develop new microbial products for mosquito control [189-191].

\subsubsection{Naturally Occurring Symbiotic Microorganisms with Anti-Pathogen Activity}

Mosquito microbiomes modulate insect immunity, and some naturally occurring symbiotic microorganisms are capable of hampering or blocking malaria parasites development within their vectors [192-194]. These symbionts have been proposed as agents to render mosquito populations refractory to Plasmodium [195]. For example, the Serratia marcescens strain Y1 promotes the activation of the insect immune system, resulting in a reduction of the number of developing oocysts after mosquitoes are challenged with an infective blood meal [196]. Similarly, another S. marcescens strain isolated from An. albimanus impairs P. vivax infection in that vector [197]. Enterobacter species isolated from wild mosquito populations in Zambia also show anti-Plasmodium activity, likely through the production of reactive oxygen species (ROS) $[192,197,198]$. Bacteria of the genus Asaia induce a basal immunity in Anopheles mosquitoes, leading to a decrease in the development of malaria parasites within their vectors [199].

The symbiotic yeast Wickerhamomyces anomalus (WaF17.12), isolated from the malaria vector mosquito Anopheles stephensi, has shown strong anti-plasmodial activity. Mosquitoes colonized with WaF17.12 developed $65.2 \%$ fewer parasites than the control group [200]. More recently, a symbiont microsporidian (Microsporidia MB) that colonizes An. arabiensis from Kenya, was shown capable of blocking P. falciparum development and transmission, providing a new prospect for malaria control [201]. 
Host-baited traps, odour-baited traps, resting traps, and sugar-baited traps have been proposed as possible ways of delivering these agents to mosquitoes [202].

\subsubsection{Paratransgenesis}

Paratransgenesis consists in genetically transformed mosquito symbionts such as fungi, viruses or bacteria to disrupt the transmission of vector-borne pathogens [203]. The perspective of applying paratransgenesis for malaria control has driven exciting research with promising results. Recombinant densovirus such as AgDNV, isolated from An. gambiae, can be used to infect mosquitoes and drive expression of anti-Plasmodium peptides to block parasite transmission or insect-specific toxins to reduce mosquito population density or mosquito lifespan [204]. Fungi carrying effector genes that hinders Plasmodium development have been genetically engineered [205]. Among the symbiotic bacteria found in malaria vectors, Asaia, Pantoea, Serratia, Pseudomonas and Thorsellia have been evaluated as candidates for paratransgenesis [206-208].

Proof-of-principle experiments conducted with An. gambiae and An. stephensis [209-211] suggest paratransgenesis can be developed in an actual tool for malaria control. Engineered Pantoea agglomerans expressing anti-plasmodial genes inhibit the development of malaria parasites by up to $98 \%$ and reduce the proportion of infected mosquitoes by $84 \%$ in lab settings [210]. Similar results were obtained with Serratia, strain AS1 [209]. With this in mind, the microbial flora associated with An. darlingi and other neotropical malaria vectors have been investigated [197,212-221]. Expanding the knowledge of culturable bacteria associated with this malaria vector and identifying symbiotic bacterial strains that are amenable to genetic manipulation, colonize An. darlingi efficiently and are transferred from adult females to their progeny, is essential for moving forward and testing the viability of paratransgenesis for malaria control in the Amazon. Recent detection of Asaia sp in An. darlingi further supports the prospect of using these bacteria as tools for malaria control through paratransgenesis in the Amazon [212,218] although several challenges remain to be addressed for field applications (i.e., effectiveness, safety and release methods).

\subsubsection{Wolbachia}

Wolbachia are common intracellular endosymbiont bacteria present in up to $60 \%$ of insect species, including mosquitoes [222-224]. They are maternally inherited and can cause reproductive alterations in their hosts, including cytoplasmic incompatibility (CI), parthenogenesis, male-killing, and feminization [223,225-227]. Furthermore, Wolbachia can inhibit the replication of pathogens in its arthropod hosts, making these organisms a promising tool to combat mosquito-transmitted diseases [228,229]. The successes of Wolbachia-based biocontrol of dengue and other arboviruses [230] suggest the possibility of similar Wolbachia-based strategies for malaria control. Additionally, applications of Wolbachia in combined incompatible and sterile insect technique (IIT-SIT) have been considered an effective and safe approach to control mosquito populations [231].

Evidences of natural Wolbachia infections in malaria vectors [232-234] triggered investigations on the possible use of Wolbachia-Anopheles associations to limit malaria transmission. These efforts generated remarkable results showing reduced egg laying (population reduction) and a significantly reduced Plasmodium prevalence in mosquitoes carrying native Wolbachia infection (population replacement) $[233,235]$. However, challenges remain for naturally occurring Wolbachia to be applicable as tools for malaria control. These strategies must rely on CI for Wolbachia to spread in natural populations and at present, it is not clear whether native Wolbachia can induce CI in anophelines. Induction of CI was not observed in caged experiments using wAnga-BF-infected An. coluzzii [235]. Nonetheless, Wolbachia-based malaria control strategies, such as population suppression or blocking of parasite development, are not only reliant on Wolbachia symbionts naturally associated with a given mosquito species. Successful dengue control was achieved with Aedes aegypti mosquitoes artificially infected with Wolbachia from a different insect species. Hence, the Wolbachia-based vector population suppression and disease transmission blocking can work in species not commonly infected with 
Wolbachia in the wild [236]. So far, the only Anopheles species amenable to Wolbachia transinfection in the laboratory is An. stephensi [237]. The wAlbB strain was used to stably infect An. stephensi, inducing complete $\mathrm{CI}$, and conferring resistance to malaria parasites [238]. Recent studies suggest paratransgenesis could be exploited to circumvent difficulties in infecting malaria vectors with living Wolbachia strains. Wolbachia-derived molecules that stimulate the mosquito immune system and modulate vector competence, could be expressed in engineered symbiotic bacteria affecting parasite development [239].

Wolbachia-based approaches for malaria control in the Amazon have not been investigated to date. Successful laboratory colonization of An. darlingi and other local malaria vectors [162-164], will allow attempts to transinfect these mosquitoes with Wolbachia. However, Wolbachia-based approaches for malaria control in the Amazon will depend on vertical transmission of Wolbachia to offspring. Additional research is needed to investigate if $\mathrm{CI}$, parthenogenesis or feminization could be induced by Wolbachia infection and to identify Wolbachia strains that affect malaria parasites development in An. darlingi and other neotropical anopheline mosquitoes.

\section{Final Remarks and Perspectives}

Despite the WHO's global efforts to control and eliminate malaria, the present malaria situation is still alarming, with an estimated 228 million yearly cases of malaria occurring worldwide, causing more than 400,000 deaths and predominantly affecting the poor and underprivileged [8]. While most malaria cases and related deaths occur in the World Health Organization (WHO) African Region (213 million or 93\%), in 2018 the Americas reported more than 750,000 confirmed malaria cases, with 130 million people living in areas at risk of malaria transmission. Approximately 200,000 malaria cases were registered in the Brazilian Amazon in 2018. With the goal of providing the deserved health care to the thousands of people living in the Amazon, and in accordance with the United Nations Sustainable Development Goal (SDG) 3, "ensure healthy lives and promote well-being for all at all ages" [240], increased investment and adequate planning will be necessary to eliminate malaria transmission in the area. Investments in malaria elimination and eradication are worthwhile, resulting in millions of lives saved, stimulating the economy and fostering prosperity, ensuring return on investment of billions of dollars [241-246].

While malaria elimination in Brazil in the near future remains unlikely [7], researchers are exploring and developing novel and promising vector-based approaches to curb malaria transmission. Along with improvements of vaccines, drugs, diagnostic tools, IRS, and insecticide-treated nets, new vector-based approaches may prove crucial for the implementation of malaria-control programs, especially in regions where existing interventions have been unable to eliminate disease transmission. The efficacy and biosafety concerning these new technologies will need to be addressed via a stepwise regulatory framework before they can be incorporated into malaria control programs. Meanwhile, research expanding the knowledge of neotropical malaria vectors' biology, ecology, behavior, physiology, genetics, biochemistry, and insecticide resistance, primarily with regards to An. darlingi, is needed, as it is the basis on which vector-based malaria control in the Amazon may be founded.

Author Contributions: All authors have read and agreed to the published version of the manuscript.

Funding: JASN (FAPESP Young Investigator Award grant \# 2013/11343-6).

Conflicts of Interest: The authors declare no conflict of interest. The funders had no role in the design of the study; in the collection, analyses, or interpretation of data; in the writing of the manuscript, or in the decision to publish the results.

\section{References}

1. WHO. From Malaria Control to Malaria Elimination: A Manual for Elimination Scenario Planning. Available online: https://www.who.int/malaria/publications/atoz/9789241507028/en/ (accessed on 20 August 2020). 
2. Antiporta, D.A.; Rosas-Aguirre, A.; Chang, J.; Llanos-Cuentas, A.; Lescano, A.G. Malaria eradication. Lancet 2020, 395, e67. [CrossRef]

3. WHO. Global Technical Strategy for Malaria 2016-2030. Available online: https://www.who.int/malaria/ publications/atoz/9789241564991/en/ (accessed on 20 April 2020).

4. WHO; UNICEF. Global Vector Control Response 2017-2030. Available online: https://www.who.int/vectorcontrol/publications/global-control-response/en/ (accessed on 18 June 2020).

5. PAHO. Plan of Action for Malaria Elimination 2016-2020. Available online: https://iris.paho.org/bitstream/ handle/10665.2/31440/CD55-13-e.pdf?sequence=1\&isAllowed (accessed on 22 April 2020).

6. Brasil, M.d.S.d. Plano de Eliminação de Malária no Brasil. Available online: https://www.saude.gov.br/ images/pdf/2017/janeiro/04/Plano-eliminacao-malaria-pub.pdf (accessed on 18 June 2020).

7. Melo, J.; Padilha, M.; Barbosa, R.; Alonso, W.; Vittor, A.; Laporta, G. Evaluation of the malaria elimination policy in Brazil: A systematic review and epidemiological analysis study. Trop. Biomed. 2020, 37, 513-535.

8. WHO. World MALARIA Report. Available online: https://www.who.int/publications/i/item/9789241565721 (accessed on 18 June 2020).

9. Wilson, A.L.; Courtenay, O.; Kelly-Hope, L.A.; Scott, T.W.; Takken, W.; Torr, S.J.; Lindsay, S.W. The importance of vector control for the control and elimination of vector-borne diseases. PLoS Negl. Trop. Dis. 2020, 14, e0007831. [CrossRef]

10. Coura, J.R.; Suárez-Mutis, M.; Ladeia-Andrade, S. A new challenge for malaria control in Brazil: Asymptomatic Plasmodium infection-a review. Mem. Inst. Oswaldo Cruz 2006, 101, 229-237. [CrossRef]

11. Deane, L.M. Malaria vectors in Brazil. Mem. Inst. Oswaldo Cruz 1986, 81, 5-14. [CrossRef]

12. Multini, L.C.; Marrelli, M.T.; Beier, J.C.; Wilke, A.B. Increasing Complexity Threatens the Elimination of Extra-Amazonian Malaria in Brazil. Trends Parasitol. 2019, 35, 383-387. [CrossRef]

13. Pina-Costa, A.d.; Brasil, P.; Santi, S.M.D.; Araujo, M.P.D.; Suárez-Mutis, M.C.; Oliveira-Ferreira, J.; Lourenço-de-Oliveira, R.; Daniel-Ribeiro, C.T. Malaria in Brazil: What happens outside the Amazonian endemic region. Mem. Inst. Oswaldo Cruz 2014, 109, 618-633. [CrossRef]

14. Brasil, M.d.S.d. Malária: O que é, Causas, Sintomas, Tratamento, Diagnóstico e Prevenção-Situação Epidemiológica da Malária. Available online: http://saude.gov.br/saude-de-a-z/malaria (accessed on 24 June 2020).

15. Sampaio, V.S.; Siqueira, A.M.; Alecrim, M.d.G.C.; Mourão, M.P.G.; Marchesini, P.B.; Albuquerque, B.C.; Nascimento, J.; Figueira, É.A.G.; Alecrim, W.D.; Monteiro, W.M. Malaria in the State of Amazonas: A typical Brazilian tropical disease influenced by waves of economic development. Rev. Soc. Bras. Med. Trop. 2015, 48, 4-11. [CrossRef]

16. Cruz, O.G. Madeira-Mamoré Railway Company: Considerações gerais sobre as condições sanitárias do rio Madeira. 1910. In Cruz, Oswaldo. Opera ominia; Instituto Oswaldo Cruz: Rio de Janeiro, Brazil, 1972; pp. 564-624.

17. Lopes, G. Anopheles gambiae in Brazil: The background to a "silent spread", 1930-1932. Historia Cienc. Saude-Manguinhos 2019, 26, 823-839. [CrossRef]

18. Parmakelis, A.; Russello, M.A.; Caccone, A.; Marcondes, C.B.; Costa, J.; Forattini, O.P.; Sallum, M.A.M.; Wilkerson, R.C.; Powell, J.R. Historical analysis of a near disaster: Anopheles gambiae in Brazil. Am. J. Trop. Med. 2008, 78, 176-178. [CrossRef]

19. Ferreira, M.U.; Castro, M.C. Challenges for malaria elimination in Brazil. Malar. J. 2016, 15, 1-18. [CrossRef] [PubMed]

20. Oliveira-Ferreira, J.; Lacerda, M.V.; Brasil, P.; Ladislau, J.L.; Tauil, P.L.; Daniel-Ribeiro, C.T. Malaria in Brazil: An overview. Malar. J. 2010, 9, 115. [CrossRef] [PubMed]

21. Killeen, G.F. Following in Soper's footsteps: Northeast Brazil 63 years after eradication of Anopheles gambiae. Lancet Infect. Dis. 2003, 3, 663-666. [CrossRef]

22. Silva, R.d.; Paiva, C.H.A. The Juscelino Kubitschek government and the Brazilian Malaria Control and Eradication Working Group: Collaboration and conflicts in Brazilian and international health agenda, 1958-1961. História, Ciências, Saúde-Manguinhos 2015, 22, 95-114. [CrossRef]

23. Da Silva, R.; Hochman, G. Um método chamado Pinotti: Sal medicamentoso, malária e saúde internacional (1952-1960). História, Ciências, Saúde-Manguinhos 2011, 18, 519-543. [CrossRef]

24. Marques, A.C. Migrations and the dissemination of malaria in Brazil. Mem. Inst. Oswaldo Cruz 1986, 81, 17-30. [CrossRef] 
25. Marques, A.C. Human migration and the spread of malaria in Brazil. Parasitol. Today 1987, 3, 166-170. [CrossRef]

26. Camargo, E.P. Malária, maleita, paludismo. Cienc. Cult. 2003, 55, 26-29.

27. Fearnside, P.M. Deforestation in Brazilian Amazonia: History, rates, and consequences. Conserv. Biol. 2005, 19, 680-688. [CrossRef]

28. Carlos, B.C.; Rona, L.D.; Christophides, G.K.; Souza-Neto, J.A. A comprehensive analysis of malaria transmission in Brazil. Pathog. Glob. Health 2019, 113, 1-13. [CrossRef]

29. Eichemberg Silva, L.C. O Que Mostram os Indicadores Sobre a Pobreza na Década Perdida; (Texto Para Discussão, 274); IPEA: Rio de Janeiro, Brazil, 1992.

30. Conn, J.E.; Grillet, M.E.; Correa, M.; Sallum, M.A.M. Malaria transmission in South America-present status and prospects for elimination. In Towards Malaria Elimination-A Leap Forward; InTech: London, UK, 2018; pp. 281-313.

31. Arruda-Barbosa, L.d.; Sales, A.F.G.; Souza, I.L.L.d. Reflexes of Venezuelan immigration on health care at the largest hospital in Roraima, Brazil: Qualitative analysis. Saude Soc. 2020, 29, e190730. [CrossRef]

32. Grillet, M.E.; Moreno, J.E.; Hernandez, J.V.; Vincenti-Gonzalez, M.F.; Noya, O.; Tami, A.; Paniz-Mondolfi, A.; Llewellyn, M.; Lowe, R.; Escalante, A.A. Malaria in Southern Venezuela: The Hottest Hotspot in Latin America. bioRxiv 2020.

33. Mosnier, E.; Roux, E.; Cropet, C.; Lazrek, Y.; Moriceau, O.; Gaillet, M.; Mathieu, L.; Nacher, M.; Demar, M.; Odonne, G. Prevalence of Plasmodium spp. in the Amazonian Border Context (French Guiana-Brazil): Associated Factors and Spatial Distribution. Am. J. Trop. Med. 2020, 102, 130-141. [CrossRef] [PubMed]

34. Tauil, P.L. Perspectives of vector borne diseases control in Brazil. Rev. Soc. Bras. Med. Trop. 2006, 39.

35. Mendes, A.M.; Lima, M.d.S.; Maciel, A.G.P.; Menezes, R.A.d.O.; Eugênio, N.C.C. Malaria among indigenous peoples on the Brazil-French Guiana border, 2007-2016: A descriptive study. Epidemiol. Serv. Saúde 2020, 29, e2019056. [PubMed]

36. Robortella, D.R.; Calvet, A.A.; Amaral, L.C.; Fantin, R.F.; Guimarães, L.F.F.; França Dias, M.H.; Brito, C.F.A.d.; Sousa, T.N.d.; Herzog, M.M.; Oliveira-Ferreira, J. Prospective assessment of malaria infection in a semi-isolated Amazonian indigenous Yanomami community: Transmission heterogeneity and predominance of submicroscopic infection. PLoS ONE 2020, 15, e0230643. [CrossRef] [PubMed]

37. Douine, M.; Lambert, Y.; Musset, L.; Hiwat, H.; Blume, L.R.; Marchesini, P.; Moresco, G.G.; Cox, H.; Sanchez, J.F.; Villegas, L. Malaria in Gold Miners in the Guianas and the Amazon: Current Knowledge and Challenges. Curr. Trop. Med. Rep. 2020,1-11. [CrossRef]

38. Mosnier, E.; Dusfour, I.; Lacour, G.; Saldanha, R.; Guidez, A.; Gomes, M.S.; Sanna, A.; Epelboin, Y.; Restrepo, J.; Davy, D. Resurgence risk for malaria, and the characterization of a recent outbreak in an Amazonian border area between French Guiana and Brazil. BMC Infect. Dis. 2020, 20, 1-14. [CrossRef]

39. Consoli, R.A.; Oliveira, R.L.d. Principais Mosquitos de Importância Sanitária no Brasil; Editora Fiocruz: Rio de Janeiro, Brasil, 1994.

40. Tadei, W.P.; Dutary Thatcher, B. Malaria vectors in the Brazilian Amazon: Anopheles of the subgenus Nyssorhynchus. Rev. Inst. Med. Trop. São Paulo 2000, 42, 87-94. [CrossRef]

41. Marrelli, M.T.; Sallum, M.A.M.; Marinotti, O. The second internal transcribed spacer of nuclear ribosomal DNA as a tool for Latin American anopheline taxonomy: A critical review. Mem. Inst. Oswaldo Cruz 2006, 101, 817-832. [CrossRef]

42. Galardo, A.K.R.; Arruda, M.; COUTO, A.A.D.A.; Wirtz, R.; Lounibos, L.P.; Zimmerman, R.H. Malaria vector incrimination in three rural riverine villages in the Brazilian Amazon. Am. J. Trop. Med. 2007, 76, 461-469. [CrossRef]

43. Klein, T.A.; Lima, J. Seasonal distribution and biting patterns of Anopheles mosquitoes in Costa Marques, Rondonia, Brazil. J. Am. Mosq. Control Assoc. 1990, 6, 700-707.

44. Arcos, A.N.; da Silva Ferreira, F.A.; da Cunha, H.B.; Tadei, W.P. Characterization of artificial larval habitats of Anopheles darlingi (Diptera: Culicidae) in the Brazilian Central Amazon. Rev. Bras. Entomol. 2018, 62, 267-274. [CrossRef]

45. Tadei, W.P.; Rodrigues, I.B.; Rafael, M.S.; Sampaio, R.T.d.M.; Mesquita, H.; Pinheiro, V.C.S.; Zequi, J.A.C.; Roque, R.A.; Dos Santos, J.M.M. Adaptative processes, control measures, genetic background, and resilience of malaria vectors and environmental changes in the Amazon region. Hydrobiologia 2017, 789, 179-196. [CrossRef] 
46. Alves, M.R.; Codeço, C.T.; Peiter, P.C.; Souza-Santos, R. Malaria and fish farming in the Brazilian Amazon Region: A strengths, weaknesses, opportunities, and threats analysis. Rev. Soc. Bras. Med. Trop. 2019, 52. [CrossRef]

47. Lourenço-de-Oliveira, R.; Luz, S.L. Simian malaria at two sites in the Brazilian Amazon-II: Vertical distribution and frequency of anopheline species inside and outside the forest. Mem. Inst. Oswaldo Cruz 1996, 91, 687-694. [CrossRef]

48. Forattini, O.P. Culicidologia Médica: Identificaçäo, Biologia e Epidemiologia: V 2; Editora da Universidade de São Paulo: Sao Paulo, Brazil, 2002; p. 860.

49. Tadei, W.P.; Santos, J.M.M.d.; Rodrigues, I.B.; Rafael, M.S. Malária e Dengue na Amazônia: Vetores e estratégias de controle. In Pesquisa e Ações em Saúde nos Institutos de Pesquisa do Ministério da Ciência e Tecnologia; Ministério da Ciência e Tecnologia: São Paulo, Brazil, 2010; pp. 113-125.

50. Rafael, M.S.; Rohde, C.; Bridi, L.C.; Tadei, W.P. Salivary polytene chromosome map of Anopheles darlingi, the main vector of neotropical malaria. Am. J. Trop. Med. 2010, 83, 241-249. [CrossRef]

51. Wolfarth-Couto, B.; Filizola, N.; Durieux, L. Seasonal pattern of malaria cases and the relationship with hydrologic variability in the Amazonas State, Brazil. Rev. Bras. Entomol. 2020, 23, e200018.

52. Olson, S.H.; Gangnon, R.; Elguero, E.; Durieux, L.; Guégan, J.-F.; Foley, J.A.; Patz, J.A. Links between climate, malaria, and wetlands in the Amazon Basin. Emerg. Infect. Dis 2009, 15, 659. [CrossRef]

53. Wolfarth, B.R.; Filizola, N.; Tadei, W.P.; Durieux, L. Epidemiological analysis of malaria and its relationships with hydrological variables in four municipalities of the State of Amazonas, Brazil. Hydrol. Sci. J. 2013, 58, 1495-1504. [CrossRef]

54. Souza, P.F.; Xavier, D.R.; Suarez Mutis, M.C.; da Mota, J.C.; Peiter, P.C.; de Matos, V.P.; Magalhães, M.d.A.F.M.; Barcellos, C. Spatial spread of malaria and economic frontier expansion in the Brazilian Amazon. PLoS ONE 2019, 14, e0217615. [CrossRef] [PubMed]

55. Chaves, L.S.M.; Fry, J.; Malik, A.; Geschke, A.; Sallum, M.A.M.; Lenzen, M. Global consumption and international trade in deforestation-associated commodities could influence malaria risk. Nat. Commun. 2020, 11, 1258. [CrossRef] [PubMed]

56. MacDonald, A.J.; Mordecai, E.A. Amazon deforestation drives malaria transmission, and malaria burden reduces forest clearing. Proc. Natl. Acad. Sci. USA 2019, 116, 22212-22218. [CrossRef] [PubMed]

57. Conn, J.E.; Wilkerson, R.C.; Segura, M.N.O.; de Souza, R.T.; Schlichting, C.D.; Wirtz, R.A.; Póvoa, M.M. Emergence of a new Neotropical malaria vector facilitated by human migration and changes in land use. Am. J. Trop. Med. 2002, 66, 18-22. [CrossRef] [PubMed]

58. Charlwood, J. Biological variation in Anopheles darlingi Root. Mem. Inst. Oswaldo Cruz 1996, 91, $391-398$. [CrossRef]

59. Montoya-Lerma, J.; Solarte, Y.A.; Giraldo-Calderón, G.I.; Quiñones, M.L.; Ruiz-López, F.; Wilkerson, R.C.; González, R. Malaria vector species in Colombia: A review. Mem. Inst. Oswaldo Cruz 2011, 106, 223-238. [CrossRef] [PubMed]

60. Elliott, R. The influence of vector behavior on malaria transmission. Am. J. Trop. Med. 1972, 21, 755-763. [CrossRef]

61. Hudson, J. Anopheles darlingi Root (Diptera: Culicidae) in the Suriname rain forest. Bull. Entomol. Res. 1984, 74, 129-142. [CrossRef]

62. Magris, M.; Rubio-Palis, Y.; Menares, C.; Villegas, L. Vector bionomics and malaria transmission in the Upper Orinoco River, Southern Venezuela. Mem. Inst. Oswaldo Cruz 2007, 102, 303-312. [CrossRef] [PubMed]

63. Quiñones, M.; Suarez, M. Indoor resting heights of some anophelines in Colombia. Proc. Natl. Acad. Sci. USA 1990, 6, 602-604.

64. Rozendaal, J. Biting and resting behavior of Anopheles darlingi in the Suriname rainforest. J. Am. Mosq. Control. Assoc. 1989, 5, 351-358. [PubMed]

65. Vittor, A.Y.; Gilman, R.H.; Tielsch, J.; Glass, G.; Shields, T.; Lozano, W.S.; Pinedo-Cancino, V.; Patz, J.A. The effect of deforestation on the human-biting rate of Anopheles darlingi, the primary vector of falciparum malaria in the Peruvian Amazon. Am. J. Trop. Med. 2006, 74, 3-11. [CrossRef]

66. Charlwood, J.; Wilkes, T. Studies on the age-composition of samples of Anopheles darlingi Root (Diptera: Culicidae) in Brazil. Bull. Entomol. Res. 1979, 69, 337-342. [CrossRef]

67. Forattini, O.P. Comportamento exófilo de Anopheles darlingi Root, em região meridional do Brasil. Rev. Saúde Públ. 1987, 21, 291-304. [CrossRef] [PubMed] 
68. Lourenço-de-Oliveira, R.; Guimarães, A.E.d.G.; Arlé, M.; Silva, T.F.d.; Castro, M.G.; Motta, M.A.; Deane, L.M. Anopheline species, some of their habits and relation to malaria in endemic areas of Rondonia State, Amazon region of Brazil. Mem. Inst. Oswaldo Cruz 1989, 84, 501-514. [CrossRef]

69. Roberts, D.; Alecrim, W.; Tavares, A.; Radke, M. The house-frequenting, host-seeking and resting behavior of Anopheles darlingi in southeastern Amazonas, Brazil. J. Am. Mosq. Control Assoc. 1987, 3, 433.

70. Tadei, W.P.; Thatcher, B.D.; Santos, J.; Scarpassa, V.M.; Rodrigues, I.B.; Rafael, M.S. Ecologic observations on anopheline vectors of malaria in the Brazilian Amazon. Am. J. Trop. Med. 1998, 59, 325-335. [CrossRef]

71. Freitas-Sibajev, M.; Conn, J.; Mitchell, S.; Cockburn, A.; Seawright, J.; Momen, H. Mitochondrial DNA and morphological analyses of Anopheles darlingi populations from Brazil (Diptera: Culicidae). Mosq. Syst. 1995, 27, 78-99.

72. Voorham, J. Intra-population plasticity of Anopheles darlingi's (Diptera, Culicidae) biting activity patterns in the state of Amapá, Brazil. Rev. Saúde Públ. 2002, 36, 75-80. [CrossRef]

73. De Oliveira, C.D.; Tadei, W.P.; Abdalla, F.C.; Paolucci Pimenta, P.F.; Marinotti, O. Multiple blood meals in Anopheles darlingi (Diptera: Culicidae). J. Vector Ecol. 2012, 37, 351-358. [CrossRef]

74. Barrón, M.G.; Paupy, C.; Rahola, N.; Akone-Ella, O.; Ngangue, M.F.; Wilson-Bahun, T.A.; Pombi, M.; Kengne, P.; Costantini, C.; Simard, F.; et al. A new species in the major malaria vector complex sheds light on reticulated species evolution. Sci. Rep. 2019, 9, 14753. [CrossRef] [PubMed]

75. Sinka, M.E.; Bangs, M.J.; Manguin, S.; Chareonviriyaphap, T.; Patil, A.P.; Temperley, W.H.; Gething, P.W.; Elyazar, I.R.F.; Kabaria, C.W.; Harbach, R.E.; et al. The dominant Anopheles vectors of human malaria in the Asia-Pacific region: Occurrence data, distribution maps and bionomic précis. Parasit Vectors 2011, 4, 89. [CrossRef] [PubMed]

76. Tripathy, A.; Samanta, L.; Das, S.; Parida, S.K.; Marai, N.; Hazra, R.K.; Kar, S.K.; Mahapatra, N. Distribution of sibling species of Anopheles culicifacies s.l. and Anopheles fluviatilis s.l. and their vectorial capacity in eight different malaria endemic districts of Orissa, India. Mem. Inst. Oswaldo Cruz 2010, 105, 981-987. [CrossRef] [PubMed]

77. Rosa-Freitas, M.G.; Lourenço-de-Oliveira, R.; Carvalho-Pinto, C.J.d.; Flores-Mendoza, C.; Silva-do-Nascimento, T.F. Anopheline Species Complexes in Brazil. Current Knowledge of Those Related to Malaria Transmission. Mem. Inst. Oswaldo Cruz 1998, 93, 651-655. [CrossRef] [PubMed]

78. Saraiva, J.F.; Souto, R.N.P.; Scarpassa, V.M. Molecular taxonomy and evolutionary relationships in the Oswaldoi-Konderi complex (Anophelinae: Anopheles: Nyssorhynchus) from the Brazilian Amazon region. PLoS ONE 2018, 13, e0193591. [CrossRef]

79. Klein, T.A.; Lima, J.B.; Tada, M.S. Comparative susceptibility of anopheline mosquitoes to Plasmodium falciparum in Rondonia, Brazil. Am. J. Trop. Med. Hyg. 1991, 44, 598-603. [CrossRef]

80. Marrelli, M.T.; Honório, N.A.; Flores-Mendoza, C.; Lourenco-de-Oliveira, R.; Marinotti, O.; Kloetzel, J.K. Comparative susceptibility of two members of the Anopheles oswaldoi complex, An. oswaldoi and An. konderi, to infection by Plasmodium vivax. Trans. R Soc. Trop. Med. Hyg. 1999, 93, 381-384. [CrossRef]

81. Bourke, B.P.; Conn, J.E.; de Oliveira, T.M.P.; Chaves, L.S.M.; Bergo, E.S.; Laporta, G.Z.; Sallum, M.A.M. Exploring malaria vector diversity on the Amazon Frontier. Malar. J. 2018, 17, 342. [CrossRef]

82. Swain, S.N.; Makunin, A.; Dora, A.S.; Barik, T.K. SNP barcoding based on decision tree algorithm: A new tool for identification of mosquito species with special reference to Anopheles. Acta Trop. 2019, 199, 105152. [CrossRef]

83. WHO. Guidelines for Malaria VECTOR Control 2019. Available online: https:/apps.who.int/iris/bitstream/ handle/10665/310862/9789241550499-eng.pdf?ua=1 (accessed on 18 June 2020).

84. WHO. Malaria Vector Control, Policy Guidance, Recommendations. Available online: https://www.who.int/ malaria/policy-guidance/vector-control\#tab=tab_2 (accessed on 5 May 2020).

85. WHO. Malaria Vector Control, Policy Guidance, Operational Manuals. Available online: https://www.who. int/malaria/policy-guidance/vector-control\#tab=tab_3 (accessed on 5 May 2020).

86. Brasil, M.d.S.d.; Saúde, S.d.V.e.; Transmissíveis, D.d.I.e.D. Guia de Tratamento da Malária no Brasil. Available online: http://bvsms.saude.gov.br/bvs/publicacoes/guia_tratamento_malaria_brasil.pdf (accessed on 5 May 2020).

87. WHO. Global Malaria Programme: Insecticide-Treated Mosquito Nets: A WHO Position Statement. Available online: https://www.who.int/mediacentre/news/releases/2007/pr43/en/ (accessed on 5 May 2020). 
88. Baia-da-Silva, D.C.; Brito-Sousa, J.D.; Rodovalho, S.R.; Peterka, C.; Moresco, G.; Lapouble, O.M.M.; Melo, G.C.d.; Sampaio, V.d.S.; Alecrim, M.d.G.C.; Pimenta, P. Current vector control challenges in the fight against malaria in Brazil. Rev. Soc. Bras. Med. Trop. 2019, 52. [CrossRef]

89. Lorenz, L.M.; Bradley, J.; Yukich, J.; Massue, D.J.; Mageni Mboma, Z.; Pigeon, O.; Moore, J.; Kilian, A.; Lines, J.; Kisinza, W.; et al. Comparative functional survival and equivalent annual cost of 3 long-lasting insecticidal net (LLIN) products in Tanzania: A randomised trial with 3-year follow up. PLoS Med. 2020, 17, e1003248. [CrossRef] [PubMed]

90. Briet, O.; Koenker, H.; Norris, L.; Wiegand, R.; Vanden Eng, J.; Thackeray, A.; Williamson, J.; Gimnig, J.E.; Fortes, F.; Akogbeto, M.; et al. Attrition, physical integrity and insecticidal activity of long-lasting insecticidal nets in sub-Saharan Africa and modelling of their impact on vectorial capacity. Malar. J. 2020, 19, 310. [CrossRef]

91. Ngufor, C.; Agbevo, A.; Fagbohoun, J.; Fongnikin, A.; Rowland, M. Efficacy of Royal Guard, a new alpha-cypermethrin and pyriproxyfen treated mosquito net, against pyrethroid-resistant malaria vectors. Sci. Rep. 2020, 10, 12227. [CrossRef] [PubMed]

92. Bayili, K.; N’do, S.; Namountougou, M.; Sanou, R.; Ouattara, A.; Dabiré, R.K.; Ouédraogo, A.G.; Malone, D.; Diabaté, A. Evaluation of efficacy of InterceptorßG2, a long-lasting insecticide net coated with a mixture of chlorfenapyr and alpha-cypermethrin, against pyrethroid resistant Anopheles gambiae s.l. in Burkina Faso. Malar. J. 2017, 16, 190. [CrossRef] [PubMed]

93. Paton, D.G.; Childs, L.M.; Itoe, M.A.; Holmdahl, I.E.; Buckee, C.O.; Catteruccia, F. Exposing Anopheles mosquitoes to antimalarials blocks Plasmodium parasite transmission. Nature 2019, 567, 239-243. [CrossRef] [PubMed]

94. De Oliveira Sousa, J.; de Albuquerque, B.C.; Coura, J.R.; Suárez-Mutis, M.C. Use and retention of long-lasting insecticidal nets (LLINs) in a malaria risk area in the Brazilian Amazon: A 5-year follow-up intervention. Malar. J. 2019, 18, 100. [CrossRef] [PubMed]

95. Vieira, G.d.D.; Basano, S.d.A.; Katsuragawa, T.H.; Camargo, L.M.A. Insecticide-treated bed nets in Rondônia, Brazil: Evaluation of their impact on malaria control. Rev. Inst. Med. Trop. São Paulo 2014, 56, $493-497$. [CrossRef]

96. Murta, F.L.G.; Mendes, M.O.; Sampaio, V.S.; Junior, A.S.B.; Díaz-Bermúdez, X.P.; Monteiro, W.M.; Lacerda, M.V.G. Misperceptions of patients and health workers regarding malaria elimination in the Brazilian Amazon: A qualitative study. Malar. J. 2019, 18, 223. [CrossRef]

97. WHO. Indoor Residual Spraying: An Operational Manual for Indoor Residual Spraying (IRS) for Malaria Transmission Control and Elimination. Available online: https://www.who.int/malaria/publications/atoz/ 9789241508940/en/ (accessed on 5 May 2020).

98. Corrêa, A.P.S.; Galardo, A.K.; Lima, L.A.; Câmara, D.C.; Müller, J.N.; Barroso, J.F.S.; Lapouble, O.M.; Rodovalho, C.M.; Ribeiro, K.A.N.; Lima, J.B.P. Efficacy of insecticides used in indoor residual spraying for malaria control: An experimental trial on various surfaces in a "test house". Malar. J. 2019, 18, 345. [CrossRef]

99. Dengela, D.; Seyoum, A.; Lucas, B.; Johns, B.; George, K.; Belemvire, A.; Caranci, A.; Norris, L.C.; Fornadel, C.M. Multi-country assessment of residual bio-efficacy of insecticides used for indoor residual spraying in malaria control on different surface types: Results from program monitoring in 17 PMI/USAID-supported IRS countries. Parasit Vectors 2018, 11, 1-14. [CrossRef]

100. Rohani, A.; Fakhriy, H.A.; Suzilah, I.; Zurainee, M.N.; Najdah, W.M.A.W.; Ariffin, M.M.; Shakirudin, N.M.; Afiq, M.S.M.; Jenarun, J.; Tanrang, Y.; et al. Indoor and outdoor residual spraying of a novel formulation of deltamethrin K-Othrine®(Polyzone) for the control of simian malaria in Sabah, Malaysia. PLoS ONE 2020, 15, e0230860. [CrossRef]

101. IVCC. NgenIRS is a Four Year Partnership (2016-2019), Led by IVCC and Funded by Unitaid, That Includes the US President's Malaria Initiative, the Global Fund, Abt Associates and PATH. Available online: https: //www.ivcc.com/market-access/ngenirs/ (accessed on 3 September 2020).

102. Antonio-Nkondjio, C.; Sandjo, N.N.; Awono-Ambene, P.; Wondji, C.S. Implementing a larviciding efficacy or effectiveness control intervention against malaria vectors: Key parameters for success. Parasit Vectors 2018, 11, 57. [CrossRef] [PubMed]

103. Fontoura, P.S.; da Costa, A.S.; Ribeiro, F.S.; Ferreira, M.S.; Castro, M.C.; Ferreira, M.U. Field Efficacy of VectoMax FG and VectoLex CG Biological Larvicides for Malaria Vector Control in Northwestern Brazil. J. Med. Entomol. 2020, 57, 942-946. [CrossRef] 
104. WHO. Larval Source Management: A Supplementary Malaria Vector Control Measure: An Operational Manual. Available online: https://apps.who.int/iris/bitstream/handle/10665/85379/9789241505604_eng.pdf (accessed on 5 May 2020).

105. Soper, F.L.; Wilson, D.B. Anopheles Gambiae in Brazil 1930 to 1940; The Rockefeller Foundation: New York, NY, USA, 1943.

106. Derua, Y.A.; Kweka, E.J.; Kisinza, W.N.; Githeko, A.K.; Mosha, F.W. Bacterial larvicides used for malaria vector control in sub-Saharan Africa: Review of their effectiveness and operational feasibility. Parasit Vectors 2019, 12, 426. [CrossRef] [PubMed]

107. Becker, N. Microbial control of mosquitoes: Management of the Upper Rhine mosquito population as a model programme. Parasitol. Today 1997, 13, 485-487. [CrossRef]

108. Kumar, A.; Sharma, V.; Sumodan, P.; Thavaselvam, D. Field trials of biolarvicide Bacillus thuringiensis var. israelensis strain 164 and the larvivorous fish Aplocheilus blocki against Anopheles stephensi for malaria control in Goa, India. J. Am. Mosq. Control Assoc. 1998, 14, 457-462.

109. Kroeger, A.; Horstick, O.; Riedl, C.; Kaiser, A.; Becker, N. The potential for malaria control with the biological larvicide Bacillus thuringiensis israelensis (Bti) in Peru and Ecuador. Acta Tropica 1995, 60, 47-57. [CrossRef]

110. Dambach, P. The use of Aquatic Predators for Larval Control of Mosquito Disease Vectors: Opportunities and Limitations. Biol. Control 2020, 104357. [CrossRef]

111. Cuthbert, R.N.; Dalu, T.; Wasserman, R.J.; Weyl, O.L.; Froneman, P.W.; Callaghan, A.; Coughlan, N.E.; Dick, J.T. Alternative prey impedes the efficacy of a natural enemy of mosquitoes. Biol. Control 2020, 141, 104146. [CrossRef]

112. Cavados, C.F.G.; Tadei, W.P.; Roque, R.A.; Regis, L.N.; de Oliveira, C.M.F.; Gil,H.B. Bacillus Entomopathogenic Based Biopesticides in Vector Control Programs in Brazil. In Bacillus Thuringiensis and Lysinibacillus Sphaericus; Springer: Berlin, Germany, 2017; pp. 223-237.

113. Carrasco-Escobar, G.; Manrique, E.; Ruiz-Cabrejos, J.; Saavedra, M.; Alava, F.; Bickersmith, S.; Prussing, C.; Vinetz, J.M.; Conn, J.E.; Moreno, M. High-accuracy detection of malaria vector larval habitats using drone-based multispectral imagery. PLoS Negl. Trop. Dis. 2019, 13, e0007105. [CrossRef]

114. Solano-Villarreal, E.; Valdivia, W.; Pearcy, M.; Linard, C.; Pasapera-Gonzales, J.; Moreno-Gutierrez, D.; Lejeune, P.; Llanos-Cuentas, A.; Speybroeck, N.; Hayette, M.-P.; et al. Malaria risk assessment and mapping using satellite imagery and boosted regression trees in the Peruvian Amazon. Sci. Rep. 2019, 9, 15173. [CrossRef] [PubMed]

115. Schoepke, A.; Steffen, R.; Gratz, N. Effectiveness of personal protection measures against mosquito bites for malaria prophylaxis in travelers. J. Travel Med. 1998, 5, 188-192. [CrossRef] [PubMed]

116. Loutan, L. Malaria: Still a threat to travellers. Int. J. Antimicrob. Agents 2003, 21, 158-163. [CrossRef]

117. Richards, S.L.; Agada, N.; Balanay, J.A.G.; White, A.V. Permethrin treated clothing to protect outdoor workers: Evaluation of different methods for mosquito exposure against populations with differing resistance status. Pathog. Glob. Health 2018, 112, 13-21. [CrossRef] [PubMed]

118. Tan, K.; Faierstein, G.B.; Xu, P.; Barbosa, R.M.; Buss, G.K.; Leal, W.S. A popular Indian clove-based mosquito repellent is less effective against Culex quinquefasciatus and Aedes aegypti than DEET. PLoS ONE 2019, 14, e0224810. [CrossRef]

119. Roberts, D.R.; Tren, R. International advocacy against DDT and other public health insecticides for malaria control. Res. Rep. Trop. Med. 2011, 2, 23.

120. Mwanga, E.P.; Mmbando, A.S.; Mrosso, P.C.; Stica, C.; Mapua, S.A.; Finda, M.F.; Kifungo, K.; Kafwenji, A.; Monroe, A.C.; Ogoma, S.B.; et al. Eave ribbons treated with transfluthrin can protect both users and non-users against malaria vectors. Malar. J. 2019, 18,1-14. [CrossRef]

121. Masalu, J.P.; Finda, M.; Killeen, G.F.; Ngowo, H.S.; Pinda, P.G.; Okumu, F.O. Creating mosquito-free outdoor spaces using transfluthrin-treated chairs and ribbons. Malar. J. 2020, 19, 109. [CrossRef]

122. Sangoro, O.P.; Gavana, T.; Finda, M.; Mponzi, W.; Hape, E.; Limwagu, A.; Govella, N.J.; Chaki, P.; Okumu, F.O. Evaluation of personal protection afforded by repellent-treated sandals against mosquito bites in south-eastern Tanzania. Malar. J. 2020, 19, 148. [CrossRef]

123. Burns, M.; Rowland, M.; N'Guessan, R.; Carneiro, I.; Beeche, A.; Ruiz, S.S.; Kamara, S.; Takken, W.; Carnevale, P.; Allan, R. Insecticide-treated plastic sheeting for emergency malaria prevention and shelter among displaced populations: An observational cohort study in a refugee setting in Sierra Leone. Am. J. Trop. Med. Hyg. 2012, 87, 242-250. [CrossRef] 
124. Kitau, J.; Oxborough, R.; Kaye, A.; Chen-Hussey, V.; Isaacs, E.; Matowo, J.; Kaur, H.; Magesa, S.M.; Mosha, F.; Rowland, M.; et al. Laboratory and experimental hut evaluation of a long-lasting insecticide treated blanket for protection against mosquitoes. Parasit Vectors 2014, 7, 129. [CrossRef] [PubMed]

125. Rowland, M.; Durrani, N.; Hewitt, S.; Mohammed, N.; Bouma, M.; Carneiro, I.; Rozendaal, J.; Schapira, A. Permethrin-treated chaddars and top-sheets: Appropriate technology for protection against malaria in Afghanistan and other complex emergencies. Trans. R Soc. Trop. Med. Hyg. 1999, 93, 465-472. [CrossRef]

126. Hoermann, A.; Tapanelli, S.; Capriotti, P.; Masters, E.K.; Habtewold, T.; Christophides, G.K.; Windbichler, N. Converting endogenous genes of the malaria mosquito into simple non-autonomous gene drives for population replacement. bioRxiv 2020. [CrossRef]

127. Raban, R.R.; Marshall, J.M.; Akbari, O.S. Progress towards engineering gene drives for population control. J. Exp. Biol. 2020, 223. [CrossRef]

128. Terenius, O.; Marinotti, O.; Sieglaff, D.; James, A.A. Molecular genetic manipulation of vector mosquitoes. Cell Host Microbe. 2008, 4, 417-423. [CrossRef] [PubMed]

129. Serebrovsky, A. On the possibility of a new method for the control of insect pests. Sterile-male technique for eradication or control of harmful insects. In Proceedings of the Panel on Application of the Sterile-Male Technique for the Eradication or Control of Harmful Species of Insects, Organised by the Joint FAO/IAEA Division of Atomic Energy in Food and Agriculture, Vienna, Austria, 27-31 May 1968; Volume 1969, pp. 123-237.

130. Benedict, M.Q.; Robinson, A.S. The first releases of transgenic mosquitoes: An argument for the sterile insect technique. Trends Parasitol. 2003, 19, 349-355. [CrossRef]

131. Thomas, D.D.; Donnelly, C.A.; Wood, R.J.; Alphey, L.S. Insect population control using a dominant, repressible, lethal genetic system. Science 2000, 287, 2474-2476. [CrossRef]

132. Knipling, E.F. Sterile-Male Method of Population Control: Successful with some insects, the method may also be effective when applied to other noxious animals. Science 1959, 130, 902-904. [CrossRef]

133. Mastrangelo, T.; Welch, J.B. An overview of the components of AW-IPM campaigns against the New World screwworm. Insects 2012, 3, 930-955. [CrossRef]

134. Orozco-Dávila, D.; Quintero, L.; Hernández, E.; Solís, E.; Artiaga, T.; Hernández, R.; Ortega, C.; Montoya, P. Mass rearing and sterile insect releases for the control of A nastrepha spp. pests in Mexico-A review. Entomol. Exp. Appl. 2017, 164, 176-187. [CrossRef]

135. Lindquist, D.; Abusowa, M.; Hall, M. The New World screwworm fly in Libya: A review of its introduction and eradication. Med. Vet. Entomol. 1992, 6, 2-8. [CrossRef] [PubMed]

136. Vargas-Terán, M.; Hursey, B.; Cunningham, E. Eradication of the screwworm from Libya using the sterile insect technique. Parasitol. Today 1994, 10, 119-122. [CrossRef]

137. Lowe, R.E.; Bailey, D.L.; Dame, D.A.; Savage, K.E.; Kaiser, P.E. Efficiency of techniques for the mass release of sterile male Anopheles albimanus Wiedemann in El Salvador. Am. J. Trop. Med. 1980, 29, 695-703. [CrossRef] [PubMed]

138. Carvalho, D.O.; McKemey, A.R.; Garziera, L.; Lacroix, R.; Donnelly, C.A.; Alphey, L.; Malavasi, A.; Capurro, M.L. Suppression of a field population of Aedes aegypti in Brazil by sustained release of transgenic male mosquitoes. PLoS Negl. Trop. Dis. 2015, 9, e0003864. [CrossRef]

139. Vreysen, M.J.; Saleh, K.; Mramba, F.; Parker, A.; Feldmann, U.; Dyck, V.A.; Msangi, A.; Bouyer, J. Sterile insects to enhance agricultural development: The case of sustainable tsetse eradication on Unguja Island, Zanzibar, using an area-wide integrated pest management approach. PLoS Negl. Trop. Dis. 2014, 8, e2857. [CrossRef]

140. Hammond, A.M.; Galizi, R. Gene drives to fight malaria: Current state and future directions. Pathog. Glob. Health 2017, 111, 412-423. [CrossRef]

141. Curtis, C. Possible use of translocations to fix desirable genes in insect pest populations. Nature 1968, 218, 368-369. [CrossRef]

142. Leftwich, P.T.; Edgington, M.P.; Harvey-Samuel, T.; Carabajal Paladino, L.Z.; Norman, V.C.; Alphey, L. Recent advances in threshold-dependent gene drives for mosquitoes. Biochem. Soc. Trans. 2018, 46, 1203-1212. [CrossRef]

143. Flores, H.A.; O'Neill, S.L. Controlling vector-borne diseases by releasing modified mosquitoes. Nat. Rev. Microbiol. 2018, 16, 508-518. [CrossRef] 
144. Quinn, C.M.; Nolan, T. Nuclease-based gene drives, an innovative tool for insect vector control: Advantages and challenges of the technology. Curr. Opin. Insect Sci. 2020, 39, 77-83. [CrossRef]

145. Kyrou, K.; Hammond, A.M.; Galizi, R.; Kranjc, N.; Burt, A.; Beaghton, A.K.; Nolan, T.; Crisanti, A. A CRISPR-Cas9 gene drive targeting doublesex causes complete population suppression in caged Anopheles gambiae mosquitoes. Nat. Biotechnol. 2018, 36, 1062-1066. [CrossRef] [PubMed]

146. Simoni, A.; Hammond, A.M.; Beaghton, A.K.; Galizi, R.; Taxiarchi, C.; Kyrou, K.; Meacci, D.; Gribble, M.; Morselli, G.; Burt, A. A male-biased sex-distorter gene drive for the human malaria vector Anopheles gambiae. Nat. Biotechnol. 2020, 1-7.

147. Hammond, A.; Galizi, R.; Kyrou, K.; Simoni, A.; Siniscalchi, C.; Katsanos, D.; Gribble, M.; Baker, D.; Marois, E.; Russell, S. A CRISPR-Cas9 gene drive system targeting female reproduction in the malaria mosquito vector Anopheles gambiae. Nat. Biotechnol. 2016, 34, 78-83. [CrossRef]

148. Galizi, R.; Doyle, L.A.; Menichelli, M.; Bernardini, F.; Deredec, A.; Burt, A.; Stoddard, B.L.; Windbichler, N.; Crisanti, A. A synthetic sex ratio distortion system for the control of the human malaria mosquito. Nat. Commun. 2014, 5, 3977. [CrossRef] [PubMed]

149. Gantz, V.M.; Jasinskiene, N.; Tatarenkova, O.; Fazekas, A.; Macias, V.M.; Bier, E.; James, A.A. Highly efficient Cas9-mediated gene drive for population modification of the malaria vector mosquito Anopheles stephensi. Proc. Natl. Acad. Sci. USA 2015, 112, E6736-E6743. [CrossRef]

150. Pham, T.B.; Phong, C.H.; Bennett, J.B.; Hwang, K.; Jasinskiene, N.; Parker, K.; Stillinger, D.; Marshall, J.M.; Carballar-Lejarazú, R.; James, A.A. Experimental population modification of the malaria vector mosquito, Anopheles stephensi. PLoS Genet. 2019, 15, e1008440. [CrossRef]

151. Akbari, O.S.; Matzen, K.D.; Marshall, J.M.; Huang, H.; Ward, C.M.; Hay, B.A. A synthetic gene drive system for local, reversible modification and suppression of insect populations. Curr. Biol. 2013, 23, 671-677. [CrossRef] [PubMed]

152. Buchman, A.; Marshall, J.M.; Ostrovski, D.; Yang, T.; Akbari, O.S. Synthetically engineered Medea gene drive system in the worldwide crop pest Drosophila suzukii. Proc. Natl. Acad. Sci. USA 2018, 115, 4725-4730. [CrossRef]

153. Kandul, N.P.; Liu, J.; Buchman, A.; Gantz, V.M.; Bier, E.; Akbari, O.S. Assessment of a split homing based gene drive for efficient knockout of multiple genes. G3-Genes Genom. Genet 2020, 10, 827-837. [CrossRef]

154. Nash, A.; Urdaneta, G.M.; Beaghton, A.K.; Hoermann, A.; Papathanos, P.A.; Christophides, G.K.; Windbichler, N. Integral gene drives for population replacement. Biol. Open 2019, 8. [CrossRef]

155. Oberhofer, G.; Ivy, T.; Hay, B.A. Cleave and Rescue, a novel selfish genetic element and general strategy for gene drive. Proc. Natl. Acad. Sci. USA 2019, 116, 6250-6259. [CrossRef] [PubMed]

156. Collins, C.; Bonds, J.; Quinlan, M.; Mumford, J. Effects of the removal or reduction in density of the malaria mosquito, Anopheles gambiae sl, on interacting predators and competitors in local ecosystems. Med. Vet. Entomol. 2019, 33, 1-15. [CrossRef] [PubMed]

157. Baker, D.A.; Nolan, T.; Fischer, B.; Pinder, A.; Crisanti, A.; Russell, S. A comprehensive gene expression atlas of sex-and tissue-specificity in the malaria vector, Anopheles gambiae. BMC Genom. 2011, 12, 1-12. [CrossRef] [PubMed]

158. Cassone, B.J.; Kay, R.G.; Daugherty, M.P.; White, B.J. Comparative transcriptomics of malaria mosquito testes: Function, evolution, and linkage. G3-Genes Genom. Genet 2017, 7, 1127-1136. [CrossRef] [PubMed]

159. Papa, F.; Windbichler, N.; Waterhouse, R.M.; Cagnetti, A.; D’Amato, R.; Persampieri, T.; Lawniczak, M.K.; Nolan, T.; Papathanos, P.A. Rapid evolution of female-biased genes among four species of Anopheles malaria mosquitoes. Genome Res. 2017, 27, 1536-1548. [CrossRef] [PubMed]

160. Rose, G.; Krzywinska, E.; Kim, J.; Revuelta, L.; Ferretti, L.; Krzywinski, J. Dosage compensation in the African malaria mosquito Anopheles gambiae. Genome Biol. Evol. 2016, 8, 411-425.

161. Taxiarchi, C.; Kranjc, N.; Kriezis, A.; Kyrou, K.; Bernardini, F.; Russell, S.; Nolan, T.; Crisanti, A.; Galizi, R. High-resolution transcriptional profiling of Anopheles gambiae spermatogenesis reveals mechanisms of sex chromosome regulation. Sci. Rep. 2019, 9, 1-12. [CrossRef]

162. Araujo, M.d.S.; Andrade, A.O.; Santos, N.A.C.d.; Pereira, D.B.; Costa, G.d.S.; Paulo, P.F.M.d.; Rios, C.T.; Moreno, M.; Pereira-da-Silva, L.H.; Medeiros, J.F.d. Brazil's first free-mating laboratory colony of Nyssorhynchus darlingi. Rev. Soc. Bras. Med. Trop. 2019, 52. [CrossRef] 
163. Moreno, M.; Tong, C.; Guzmán, M.; Chuquiyauri, R.; Llanos-Cuentas, A.; Rodriguez, H.; Gamboa, D.; Meister, S.; Winzeler, E.A.; Maguina, P. Infection of laboratory-colonized Anopheles darlingi mosquitoes by Plasmodium vivax. Am. J. Trop. Med. 2014, 90, 612-616. [CrossRef]

164. Villarreal-Treviño, C.; Vásquez, G.M.; López-Sifuentes, V.M.; Escobedo-Vargas, K.; Huayanay-Repetto, A.; Linton, Y.-M.; Flores-Mendoza, C.; Lescano, A.G.; Stell, F.M. Establishment of a free-mating, long-standing and highly productive laboratory colony of Anopheles darlingi from the Peruvian Amazon. Malar. J. 2015, 14, 227. [CrossRef]

165. Marinotti, O.; Cerqueira, G.C.; De Almeida, L.G.P.; Ferro, M.I.T.; Loreto, E.L.d.S.; Zaha, A.; Teixeira, S.M.; Wespiser, A.R.; Almeida e Silva, A.; Schlindwein, A.D. The genome of Anopheles darlingi, the main neotropical malaria vector. Nucleic Acids Res. 2013, 41, 7387-7400. [CrossRef] [PubMed]

166. Compton, A.; Sharakhov, I.V.; Tu, Z. Recent Advances and Future Perspectives in Vector-omics. Curr. Opin. Insect Sci. 2020, 40, 94-103. [CrossRef] [PubMed]

167. Da Silva, A.N.; Dos Santos, C.C.; Lacerda, R.N.; Santa Rosa, E.P.; De Souza, R.T.; Galiza, D.; Sucupira, I.; Conn, J.E.; Póvoa, M.M. Laboratory colonization of Anopheles aquasalis (Diptera: Culicidae) in Belém, Pará, Brazil. J. Med. Entomol. 2006, 43, 107-109. [CrossRef]

168. Giglio, N.; Sousa-Lima, A.; Gallardo, A.; Lima, J. Laboratory Colonization of Anopheles (Nyssorhynchus) marajoara (Diptera: Culicidae) by Induced Copulation. J. Med. Entomol. 2015, 52, 3-8. [CrossRef] [PubMed]

169. Horosko, S.; Lima, J.B.; Brandolini, M. Establishment of a free-mating colony of Anopheles albitarsis from Brazil. J. Am. Mosq. Control Assoc. 1997, 95-96.

170. Dahmana, H.; Mediannikov, O. Mosquito-Borne Diseases Emergence/Resurgence and How to Effectively Control It Biologically. Pathogens 2020, 9, 310. [CrossRef] [PubMed]

171. Poopathi, S.; Mani, C.; Thirugnanasambantham, K.; Praba, V.L.; Ahangar, N.A.; Balagangadharan, K. Identification and characterization of a novel marine Bacillus cereus for mosquito control. Parasitol. Res. 2014, 113, 323-332. [CrossRef]

172. Sharma, L.; Bohra, N.; Singh, R.K.; Marques, G. Potential of Entomopathogenic Bacteria and Fungi. In Microbes for Sustainable Insect Pest Management; Springer: Cham, Switzerland, 2019; pp. 115-149.

173. Soares-da-Silva, J.; Queirós, S.G.; de Aguiar, J.S.; Viana, J.L.; dos RAV Neta, M.; da Silva, M.C.; Pinheiro, V.C.; Polanczyk, R.A.; Carvalho-Zilse, G.A.; Tadei, W.P. Molecular characterization of the gene profile of Bacillus thuringiensis Berliner isolated from Brazilian ecosystems and showing pathogenic activity against mosquito larvae of medical importance. Acta Trop. 2017, 176, 197-205. [CrossRef]

174. Arantes, O.; Vilas-Bôas, L.; Vilas-Bôas, G. Bacillus thuringiensis: Estratégias no controle biológico. In Biotecnologia: Avanços na Agricultura e na Agroindústria; Agropecuária: Rio de Janeiro, Brazil, 2002; pp. 269-293.

175. Galardo, A.K.R.; Zimmerman, R.; Galardo, C.D. Larval control of Anopheles (Nyssorhinchus) darlingiusing granular formulation of Bacillus sphaericus in abandoned gold-miners excavation pools in the Brazilian Amazon Rainforest. Rev. Soc. Bras. Med. Trop. 2013, 46, 172-177. [CrossRef]

176. Fillinger, U.; Knols, B.G.; Becker, N. Efficacy and efficiency of new Bacillus thuringiensis var. israelensis and Bacillus sphaericus formulations against Afrotropical anophelines in Western Kenya. Trop. Med. Int. Health 2003, 8, 37-47. [CrossRef]

177. Majambere, S.; Pinder, M.; Fillinger, U.; Ameh, D.; Conway, D.J.; Green, C.; Jeffries, D.; Jawara, M.; Milligan, P.J.; Hutchinson, R. Is mosquito larval source management appropriate for reducing malaria in areas of extensive flooding in The Gambia? A cross-over intervention trial. Am. J. Trop. Med. 2010, 82, 176-184. [CrossRef] [PubMed]

178. Afrane, Y.A.; Mweresa, N.G.; Wanjala, C.L.; Gilbreath III, T.M.; Zhou, G.; Lee, M.-C.; Githeko, A.K.; Yan, G. Evaluation of long-lasting microbial larvicide for malaria vector control in Kenya. Malar. J. 2016, 15, 1-9. [CrossRef] [PubMed]

179. Derua, Y.A.; Kahindi, S.C.; Mosha, F.W.; Kweka, E.J.; Atieli, H.E.; Wang, X.; Zhou, G.; Lee, M.C.; Githeko, A.K.; Yan, G. Microbial larvicides for mosquito control: Impact of long lasting formulations of Bacillus thuringiensis var. israelensis and Bacillus sphaericus on non-target organisms in western Kenya highlands. Ecol. Evol. 2018, 8, 7563-7573. [CrossRef]

180. Zhou, G.; Wiseman, V.; Atieli, H.E.; Lee, M.-C.; Githeko, A.K.; Yan, G. The impact of long-lasting microbial larvicides in reducing malaria transmission and clinical malaria incidence: Study protocol for a cluster randomized controlled trial. Trials 2016, 17, 423. [CrossRef] [PubMed] 
181. Johnson, B.J.; Manby, R.; Devine, G.J. Performance of an aerially applied liquid Bacillus thuringiensis var. israelensis formulation (strain AM65-52) against mosquitoes in mixed saltmarsh-mangrove systems and fine-scale mapping of mangrove canopy cover using affordable drone-based imagery. Pest Manag. Sci. 2020. [CrossRef]

182. Ramirez, J.L.; Short, S.M.; Bahia, A.C.; Saraiva, R.G.; Dong, Y.; Kang, S.; Tripathi, A.; Mlambo, G.; Dimopoulos, G. Chromobacterium Csp_P reduces malaria and dengue infection in vector mosquitoes and has entomopathogenic and in vitro anti-pathogen activities. PLoS Pathog. 2014, 10, e1004398. [CrossRef]

183. Short, S.M.; Van Tol, S.; MacLeod, H.J.; Dimopoulos, G. Hydrogen cyanide produced by the soil bacterium Chromobacterium sp. Panama contributes to mortality in Anopheles gambiae mosquito larvae. Sci. Rep. 2018, 8, 8358. [CrossRef]

184. Valero-Jiménez, C.A.; van Kan, J.A.; Koenraadt, C.J.; Zwaan, B.J.; Schoustra, S.E. Experimental evolution to increase the efficacy of the entomopathogenic fungus Beauveria bassiana against malaria mosquitoes: Effects on mycelial growth and virulence. Evol. Appl. 2017, 10, 433-443. [CrossRef]

185. Lovett, B.; Bilgo, E.; Diabate, A.; St. Leger, R. A review of progress toward field application of transgenic mosquitocidal entomopathogenic fungi. Pest Manag. Sci. 2019, 75, 2316-2324. [CrossRef]

186. Azizoglu, U.; Jouzani, G.S.; Yilmaz, N.; Baz, E.; Ozkok, D. Genetically modified entomopathogenic bacteria, recent developments, benefits and impacts: A review. Sci. Total Environ. 2020, 734, 139169. [CrossRef]

187. Federici, B.A. Recombinant bacterial larvicides for control of important mosquito vectors of disease. In Vector Biology, Ecology and Control; Springer: Dordrecht, The Netherlands, 2010; pp. 163-176.

188. Federici, B.A.; Park, H.-W.; Bideshi, D.K.; Wirth, M.C.; Johnson, J.J.; Sakano, Y.; Tang, M. Developing recombinant bacteria for control of mosquito larvae. J. Am. Mosq. Control Assoc. 2007, 23, 164-175. [CrossRef]

189. Borovsky, D.; Nauwelaers, S.; Shatters, R., Jr. Biochemical and Molecular Characterization of Pichia pastoris Cells Expressing Multiple TMOF Genes (tmfA) for Mosquito Larval Control. Front. Physiol. 2020, 11, 527. [CrossRef] [PubMed]

190. Deng, S.-Q.; Zou, W.-H.; Li, D.-L.; Chen, J.-T.; Huang, Q.; Zhou, L.-J.; Tian, X.-X.; Chen, Y.-J.; Peng, H.-J. Expression of Bacillus thuringiensis toxin $\mathrm{Cyt} 2 \mathrm{Ba}$ in the entomopathogenic fungus Beauveria bassiana increases its virulence towards Aedes mosquitoes. PLoS. Negl. Trop. Dis. 2019, 13, e0007590. [CrossRef] [PubMed]

191. Karabörklü, S.; Azizoglu, U.; Azizoglu, Z.B. Recombinant entomopathogenic agents: A review of biotechnological approaches to pest insect control. World J. Microbiol. Biotechnol. 2018, 34, 14. [CrossRef]

192. Cirimotich, C.M.; Dong, Y.; Clayton, A.M.; Sandiford, S.L.; Souza-Neto, J.A.; Mulenga, M.; Dimopoulos, G. Natural microbe-mediated refractoriness to Plasmodium infection in Anopheles gambiae. Science 2011, 332, 855-858. [CrossRef]

193. Dong, Y.; Manfredini, F.; Dimopoulos, G. Implication of the mosquito midgut microbiota in the defense against malaria parasites. PLoS Pathog. 2009, 5, e1000423. [CrossRef]

194. Ramirez, J.L.; Souza-Neto, J.; Cosme, R.T.; Rovira, J.; Ortiz, A.; Pascale, J.M.; Dimopoulos, G. Reciprocal tripartite interactions between the Aedes aegypti midgut microbiota, innate immune system and dengue virus influences vector competence. PLoS Negl. Trop. Dis. 2012, 6, e1561. [CrossRef]

195. Van Tol, S.; Dimopoulos, G. Influences of the mosquito microbiota on vector competence. In Advances in Insect Physiology; Elsevier: Amsterdam, The Netherlands, 2016; Volume 51, pp. 243-291.

196. Bai, L.; Wang, L.; Vega-Rodríguez, J.; Wang, G.; Wang, S. A Gut Symbiotic Bacterium Serratia marcescens Renders Mosquito Resistance to Plasmodium Infection Through Activation of Mosquito Immune Responses. Front. Microbiol. 2019, 10. [CrossRef]

197. Gonzalez-Ceron, L.; Santillan, F.; Rodriguez, M.H.; Mendez, D.; Hernandez-Avila, J.E. Bacteria in midguts of field-collected Anopheles albimanus block Plasmodium vivax sporogonic development. J. Med. Entomol. 2003, 40, 371-374. [CrossRef]

198. Dennison, N.J.; Saraiva, R.G.; Cirimotich, C.M.; Mlambo, G.; Mongodin, E.F.; Dimopoulos, G. Functional genomic analyses of Enterobacter, Anopheles and Plasmodium reciprocal interactions that impact vector competence. Malar. J. 2016, 15, 1-15. [CrossRef]

199. Cappelli, A.; Damiani, C.; Mancini, M.V.; Valzano, M.; Rossi, P.; Serrao, A.; Ricci, I.; Favia, G. Asaia activates immune genes in mosquito eliciting an anti-Plasmodium response: Implications in Malaria control. Front. Genet. 2019, 10, 836. [CrossRef] 
200. Cappelli, A.; Valzano, M.; Cecarini, V.; Bozic, J.; Rossi, P.; Mensah, P.; Amantini, C.; Favia, G.; Ricci, I. Killer yeasts exert anti-plasmodial activities against the malaria parasite Plasmodium berghei in the vector mosquito Anopheles stephensi and in mice. Parasit Vectors 2019, 12, 329. [CrossRef] [PubMed]

201. Herren, J.K.; Mbaisi, L.; Mararo, E.; Makhulu, E.E.; Mobegi, V.A.; Butungi, H.; Mancini, M.V.; Oundo, J.W.; Teal, E.T.; Pinaud, S. A microsporidian impairs Plasmodium falciparum transmission in Anopheles arabiensis mosquitoes. Nat. Commun. 2020, 11, 1-10. [CrossRef] [PubMed]

202. Sougoufara, S.; Ottih, E.C.; Tripet, F. The need for new vector control approaches targeting outdoor biting Anopheline malaria vector communities. Parasit Vectors 2020, 13, 1-15. [CrossRef] [PubMed]

203. Huang, W.; Wang, S.; Jacobs-Lorena, M. Use of Microbiota to Fight Mosquito-Borne Disease. Front. Genet. 2020, 11. [CrossRef]

204. Ren, X.; Hoiczyk, E.; Rasgon, J.L. Viral paratransgenesis in the malaria vector Anopheles gambiae. PLoS Pathog. 2008, 4, e1000135. [CrossRef]

205. Fang, W.; Vega-Rodríguez, J.; Ghosh, A.K.; Jacobs-Lorena, M.; Kang, A.; Leger, R.J.S. Development of transgenic fungi that kill human malaria parasites in mosquitoes. Science 2011, 331, 1074-1077. [CrossRef]

206. Mancini, M.V.; Spaccapelo, R.; Damiani, C.; Accoti, A.; Tallarita, M.; Petraglia, E.; Rossi, P.; Cappelli, A.; Capone, A.; Peruzzi, G. Paratransgenesis to control malaria vectors: A semi-field pilot study. Parasit Vectors 2016, 9, 1-9. [CrossRef]

207. Raharimalala, F.N.; Boukraa, S.; Bawin, T.; Boyer, S.; Francis, F. Molecular detection of six (endo-) symbiotic bacteria in Belgian mosquitoes: First step towards the selection of appropriate paratransgenesis candidates. Parasitol. Res. 2016, 115, 1391-1399. [CrossRef]

208. Villegas, L.M.; Pimenta, P.F.P. Metagenomics, paratransgenesis and the Anopheles microbiome: A portrait of the geographical distribution of the anopheline microbiota based on a meta-analysis of reported taxa. Mem. Inst. Oswaldo Cruz 2014, 109, 672-684. [CrossRef]

209. Wang, S.; Dos-Santos, A.L.; Huang, W.; Liu, K.C.; Oshaghi, M.A.; Wei, G.; Agre, P.; Jacobs-Lorena, M. Driving mosquito refractoriness to Plasmodium falciparum with engineered symbiotic bacteria. Science 2017, 357, 1399-1402. [CrossRef]

210. Wang, S.; Ghosh, A.K.; Bongio, N.; Stebbings, K.A.; Lampe, D.J.; Jacobs-Lorena, M. Fighting malaria with engineered symbiotic bacteria from vector mosquitoes. Proc. Natl. Acad. Sci. USA 2012, 109, 12734-12739. [CrossRef]

211. Yoshida, S.; Ioka, D.; Matsuoka, H.; Endo, H.; Ishii, A. Bacteria expressing single-chain immunotoxin inhibit malaria parasite development in mosquitoes. Mol. Biochem. Parasitol. 2001, 113, 89-96. [CrossRef]

212. Arruda, A.; Ferreira, G.S.; da Silva Lima, N.C.; dos Santos Júnior, A.; Custódio, M.G.F.; Benevides-Matos, N.; Ozaki, L.S.; Stabeli, R.G.; Silva, A.A. A simple methodology to collect culturable bacteria from feces of Anopheles darlingi (Diptera: Culicidae). J. Microbiol. Methods 2017, 141, 115-117. [CrossRef] [PubMed]

213. Bascuñán, P.; Niño-Garcia, J.P.; Galeano-Castañeda, Y.; Serre, D.; Correa, M.M. Factors shaping the gut bacterial community assembly in two main Colombian malaria vectors. Microbiome 2018, 6, 1-12. [CrossRef] [PubMed]

214. Galeano-Castañeda, Y.; Bascuñán, P.; Serre, D.; Correa, M.M. Trans-stadial fate of the gut bacterial microbiota in Anopheles albimanus. Acta Tropica 2020, 201, 105204. [CrossRef] [PubMed]

215. Galeano-Castañeda, Y.; Urrea-Aguirre, P.; Piedrahita, S.; Bascuñán, P.; Correa, M.M. Composition and structure of the culturable gut bacterial communities in Anopheles albimanus from Colombia. PLoS ONE 2019, 14, e0225833. [CrossRef] [PubMed]

216. Kämpfer, P.; Glaeser, S.P.; Marinotti, O.; Guy, L.; Håkansson, S.; Tadei, W.P.; Busse, H.-J.; Terenius, O. Coetzeea brasiliensis gen. nov., sp. nov. isolated from larvae of Anopheles darlingi. Int. J. Syst. Evol. Microbiol. 2016, 66, 5211-5217. [CrossRef]

217. Nilsson, L.K.; de Oliveira, M.R.; Marinotti, O.; Rocha, E.M.; Håkansson, S.; Tadei, W.P.; de Souza, A.Q.L.; Terenius, O. Characterization of Bacterial Communities in Breeding Waters of Anopheles darlingi in Manaus in the Amazon Basin Malaria-Endemic Area. Microb. Ecol. 2019, 78, 781-791. [CrossRef]

218. Oliveira, T.M.; Sanabani, S.S.; Sallum, M.A.M. Asaia (Rhodospirillales: Acetobacteraceae) and Serratia (Enterobacterales: Yersiniaceae) associated with Nyssorhynchus braziliensis and Nyssorhynchus darlingi (Diptera: Culicidae). Rev. Bras. Entomol. 2020, 64. [CrossRef]

219. Oliveira, T.M.P.; Sanabani, S.S.; Sallum, M.A.M. Bacterial diversity associated with the abdomens of naturally Plasmodium-infected and non-infected Nyssorhynchus darlingi. BMC Microbiol. 2020, 20, 1-8. [CrossRef] 
220. Prussing, C.; Saavedra, M.P.; Bickersmith, S.A.; Alava, F.; Guzmán, M.; Manrique, E.; Carrasco-Escobar, G.; Moreno, M.; Gamboa, D.; Vinetz, J.M. Malaria vector species in Amazonian Peru co-occur in larval habitats but have distinct larval microbial communities. PLoS Negl. Trop. Dis. 2019, 13, e0007412. [CrossRef]

221. Terenius, O.; De Oliveira, C.D.; Pinheiro, W.D.; Tadei, W.P.; James, A.A.; Marinotti, O. 16S rRNA gene sequences from bacteria associated with adult Anopheles darlingi (Diptera: Culicidae) mosquitoes. J. Med. Entomol. 2008, 45, 172-175. [CrossRef]

222. Hilgenboecker, K.; Hammerstein, P.; Schlattmann, P.; Telschow, A.; Werren, J.H. How many species are infected with Wolbachia?-a statistical analysis of current data. FEMS Microbiol. Lett. 2008, 281, 215-220. [CrossRef]

223. Sinkins, S.P. Wolbachia and cytoplasmic incompatibility in mosquitoes. Insect Biochem. Mol. Biol. 2004, 34, 723-729. [CrossRef]

224. Werren, J.H.; Baldo, L.; Clark, M.E. Wolbachia: Master manipulators of invertebrate biology. Nat. Rev. Microbiol. 2008, 6, 741-751. [CrossRef]

225. Rousset, F.; Bouchon, D.; Pintureau, B.; Juchault, P.; Solignac, M. Wolbachia endosymbionts responsible for various alterations of sexuality in arthropods. Proc. R. Soc. B 1992, 250, 91-98.

226. Stouthamer, R.; Breeuwer, J.A.; Hurst, G.D. Wolbachia pipientis: Microbial manipulator of arthropod reproduction. Annu. Rev. Microbiol. 1999, 53, 71-102. [CrossRef]

227. Yen, J.H.; Barr, A.R. New hypothesis of the cause of cytoplasmic incompatibility in Culex pipiens L. Nature 1971, 232, 657-658. [CrossRef]

228. Caragata, E.P.; Dutra, H.L.; Moreira, L.A. Exploiting intimate relationships: Controlling mosquito-transmitted disease with Wolbachia. Trends Parasitol. 2016, 32, 207-218. [CrossRef]

229. Hughes, G.L.; Koga, R.; Xue, P.; Fukatsu, T.; Rasgon, J.L. Wolbachia infections are virulent and inhibit the human malaria parasite Plasmodium falciparum in Anopheles gambiae. PLoS Pathog. 2011, 7, e1002043. [CrossRef] [PubMed]

230. Ferreira, A.G.; Fairlie, S.; Moreira, L.A. Insect vectors endosymbionts as solutions against diseases. Curr. Opin. Insect Sci. 2020, 40, 56-61. [CrossRef]

231. Zhang, D.; Xi, Z.; Li, Y.; Wang, X.; Yamada, H.; Qiu, J.; Liang, Y.; Zhang, M.; Wu, Y.; Zheng, X. Toward implementation of combined incompatible and sterile insect techniques for mosquito control: Optimized chilling conditions for handling Aedes albopictus male adults prior to release. PLoS Negl. Trop. Dis. 2020, 14, e0008561. [CrossRef] [PubMed]

232. Baldini, F.; Segata, N.; Pompon, J.; Marcenac, P.; Shaw, W.R.; Dabiré, R.K.; Diabaté, A.; Levashina, E.A.; Catteruccia, F. Evidence of natural Wolbachia infections in field populations of Anopheles gambiae. Nat. Commun. 2014, 5, 3985. [CrossRef]

233. Gomes, F.M.; Hixson, B.L.; Tyner, M.D.; Ramirez, J.L.; Canepa, G.E.; e Silva, T.L.A.; Molina-Cruz, A.; Keita, M.; Kane, F.; Traoré, B. Effect of naturally occurring Wolbachia in Anopheles gambiae sl mosquitoes from Mali on Plasmodium falciparum malaria transmission. Proc. Natl. Acad. Sci. USA 2017, 114, 12566-12571. [CrossRef] [PubMed]

234. Jeffries, C.L.; Lawrence, G.G.; Golovko, G.; Kristan, M.; Orsborne, J.; Spence, K.; Hurn, E.; Bandibabone, J.; Tantely, L.M.; Raharimalala, F.N. Novel Wolbachia strains in Anopheles malaria vectors from sub-Saharan Africa. Wellcome Open Res. 2018, 3. [CrossRef] [PubMed]

235. Shaw, W.R.; Marcenac, P.; Childs, L.M.; Buckee, C.O.; Baldini, F.; Sawadogo, S.P.; Dabiré, R.K.; Diabaté, A.; Catteruccia, F. Wolbachia infections in natural Anopheles populations affect egg laying and negatively correlate with Plasmodium development. Nat. Commun. 2016, 7, 1-7. [CrossRef] [PubMed]

236. Chrostek, E.; Gerth, M. Is Anopheles gambiae a natural host of Wolbachia? MBio 2019, 10. [CrossRef] [PubMed]

237. Joshi, D.; Pan, X.; McFadden, M.J.; Bevins, D.; Liang, X.; Lu, P.; Thiem, S.; Xi, Z. The maternally inheritable Wolbachia wAlbB induces refractoriness to Plasmodium berghei in Anopheles stephensi. Front. Microbiol. 2017, 8, 366. [CrossRef]

238. Bian, G.; Joshi, D.; Dong, Y.; Lu, P.; Zhou, G.; Pan, X.; Xu, Y.; Dimopoulos, G.; Xi, Z. Wolbachia invades Anopheles stephensi populations and induces refractoriness to Plasmodium infection. Science 2013, 340, 748-751. [CrossRef] 
239. Epis, S.; Varotto-Boccazzi, I.; Crotti, E.; Damiani, C.; Giovati, L.; Mandrioli, M.; Biggiogera, M.; Gabrieli, P.; Genchi, M.; Polonelli, L. Chimeric symbionts expressing a Wolbachia protein stimulate mosquito immunity and inhibit filarial parasite development. Commun. Biol. 2020, 3, 1-10. [CrossRef] [PubMed]

240. United Nations General Assembly. Transforming Our World: The 2030 Agenda for Sustainable Development; Division for Sustainable Development Goals: New York, NY, USA, 2015.

241. Akhavan, D.; Musgrove, P.; Abrantes, A.; Gusmão, R.d.A. Cost-effective malaria control in Brazil: Cost-effectiveness of a malaria control program in the Amazon Basin of Brazil, 1988-1996. Soc. Sci. Med. 1999, 49, 1385-1399. [CrossRef]

242. Bôtto-Menezes, C.; Bardají, A.; dos Santos Campos, G.; Fernandes, S.; Hanson, K.; Martínez-Espinosa, F.E.; Menéndez, C.; Sicuri, E. Costs associated with malaria in pregnancy in the Brazilian Amazon, a low endemic area where Plasmodium vivax predominates. PLoS Negl. Trop. Dis. 2016, 10, e0004494. [CrossRef] [PubMed]

243. Dev, V.; Manguin, S. Fast Forward: From Malaria Elimination to Malaria Eradication. Available online: https://blogs.biomedcentral.com/bugbitten/2020/06/16/fast-forward-from-malaria-elimination-tomalaria-eradication/ (accessed on 17 June 2020).

244. Pang, L.W.; Piovesan-Alves, F. Economic advantage of a community-based malaria management program in the Brazilian Amazon. Am. J. Trop. Med. 2001, 65, 883-886. [CrossRef]

245. Shretta, R.; Avanceña, A.L.; Hatefi, A. The economics of malaria control and elimination: A systematic review. Malar. J. 2016, 15, 593. [CrossRef]

246. Huang, C.-Y.; Zhang, S.-Y.; Chen, Z.-Y.; Xie, H.-G.; Yang, R.O. Cost-benefit analysis of malaria elimination phase surveillance measures in Fujian Province. Res. Sq. 2020. [CrossRef]

Publisher's Note: MDPI stays neutral with regard to jurisdictional claims in published maps and institutional affiliations. 